\title{
Article \\ Selective Targeting of Human and Animal Pathogens of the Helicobacter Genus by Flavodoxin Inhibitors: Efficacy, Synergy, Resistance and Mechanistic Studies
}

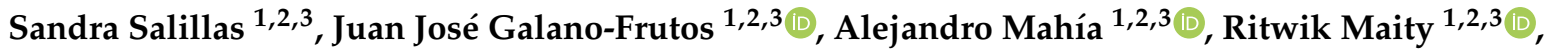 \\ María Conde-Giménez ${ }^{1,2,3}$, Ernesto Anoz-Carbonell ${ }^{1,2,4}$, Helena Berlamont ${ }^{5}{ }^{\circ}$, \\ Adrian Velazquez-Campoy ${ }^{1,2,3,6,7}{ }^{(}$, Eliette Touati ${ }^{8}$, Uwe Mamat ${ }^{9}$, Ulrich E. Schaible ${ }^{9}{ }^{\circledR}$, José A. Gálvez ${ }^{10}{ }^{1}$, \\ María D. Díaz-de-Villegas ${ }^{10}$, Freddy Haesebrouck ${ }^{5}{ }^{(\mathbb{D}}$, José A. Aínsa ${ }^{1,3,4,11}$ (1) and Javier Sancho ${ }^{1,2,3, *(\mathbb{D})}$
}

1 Biocomputation and Complex Systems Physics Institute (BIFI)-Joint Units: BIFI-IQFR (CSIC) and GBsC-CSIC, University of Zaragoza, 50018 Zaragoza, Spain; sandrasalillasberges@gmail.com (S.S.); juanjogf@gmail.com (J.J.G.-F.); amahia@unizar.es (A.M.); mr.ritwikmaity@outlook.com (R.M.); mcondeg@unizar.es (M.C.-G.); eanoz@unizar.es (E.A.-C.); adrianvc@unizar.es (A.V.-C.); ainsa@unizar.es (J.A.A.)

2 Departamento de Bioquímica y Biología Molecular y Celular, Faculty of Science, University of Zaragoza, 50009 Zaragoza, Spain

3 Aragon Health Research Institute (IIS Aragón), 50009 Zaragoza, Spain

check for updates

Citation: Salillas, S.; Galano-Frutos, J.J.; Mahía, A.; Maity, R.;

Conde-Giménez, M.; Anoz-Carbonell, E.; Berlamont, H.; Velazquez-Campoy,

A.; Touati, E.; Mamat, U.; et al. Selective Targeting of Human and Animal Pathogens of the Helicobacter Genus by Flavodoxin Inhibitors: Efficacy, Synergy, Resistance and Mechanistic Studies. Int. J. Mol. Sci. 2021, 22, 10137. https://doi.org/ 10.3390/ijms221810137

Academic Editor: Francesca Micoli

Received: 28 July 2021

Accepted: 16 September 2021

Published: 20 September 2021

Publisher's Note: MDPI stays neutral with regard to jurisdictional claims in published maps and institutional affiliations.

Copyright: () 2021 by the authors. Licensee MDPI, Basel, Switzerland. This article is an open access article distributed under the terms and conditions of the Creative Commons Attribution (CC BY) license (https:// creativecommons.org/licenses/by/ $4.0 /)$
4 Departamento de Microbiología, Pediatría, Radiología y Salud Pública, Faculty of Medicine, University of Zaragoza, 50009 Zaragoza, Spain

5 Department of Pathobiology, Pharmacology and Zoological Medicine, Faculty of Veterinary Medicine, Ghent University, Salisburylaan 133, B9820 Merelbeke, Belgium; Helena.Berlamont@UGent.be (H.B.); freddy.haesebrouck@ugent.be (F.H.)

6 ARAID Foundation, Government of Aragon, 50018 Zaragoza, Spain

7 CIBER de Enfermedades Hepáticas y Digestivas CIBERehd, Instituto de Salud Carlos III, 28029 Madrid, Spain

8 Unit of Helicobacter Pathogenesis, CNRS UMR2001, Department of Microbiology, Institut Pasteur, 25-28 Rue du Dr. Roux, 75724 Paris, France; eliette.touati@pasteur.fr

9 Cellular Microbiology, Program Area Infections, Research Center Borstel, Leibniz Lung Center, 23845 Borstel, Germany; umamat@fz-borstel.de (U.M.); uschaible@fz-borstel.de (U.E.S.)

10 Instituto de Síntesis Química y Catálisis Homogénea (ISQCH), CSIC-Departamento de Química Orgánica, Faculty of Science, University of Zaragoza, 50009 Zaragoza, Spain; jagl@unizar.es (J.A.G.); loladiaz@unizar.es (M.D.D.-d.-V.)

11 CIBER de Enfermedades Respiratorias_CIBERES, Instituto de Salud Carlos III, 28029 Madrid, Spain

* Correspondence: jsancho@unizar.es

Abstract: Antimicrobial resistant (AMR) bacteria constitute a global health concern. Helicobacter pylori is a Gram-negative bacterium that infects about half of the human population and is a major cause of peptic ulcer disease and gastric cancer. Increasing resistance to triple and quadruple $H$. pylori eradication therapies poses great challenges and urges the development of novel, ideally narrow spectrum, antimicrobials targeting $H$. pylori. Here, we describe the antimicrobial spectrum of a family of nitrobenzoxadiazol-based antimicrobials initially discovered as inhibitors of flavodoxin: an essential H. pylori protein. Two groups of inhibitors are described. One group is formed by narrow-spectrum compounds, highly specific for $H$. pylori, but ineffective against enterohepatic Helicobacter species and other Gram-negative or Gram-positive bacteria. The second group includes extended-spectrum antimicrobials additionally targeting Gram-positive bacteria, the Gram-negative Campylobacter jejuni, and most Helicobacter species, but not affecting other Gram-negative pathogens. To identify the binding site of the inhibitors in the flavodoxin structure, several $H$. pylori-flavodoxin variants have been engineered and tested using isothermal titration calorimetry. An initial study of the inhibitors capacity to generate resistances and of their synergism with antimicrobials commonly used in H. pylori eradication therapies is described. The narrow-spectrum inhibitors, which are expected to affect the microbiota less dramatically than current antimicrobial drugs, offer an opportunity to develop new and specific H. pylori eradication combinations to deal with AMR in H. pylori. On the other hand, the extended-spectrum inhibitors constitute a new family of promising antimicrobials, with a potential use against AMR Gram-positive bacterial pathogens. 
Keywords: Helicobacter; narrow-spectrum antimicrobial; AMR; flavodoxin; drug discovery

\section{Introduction}

Helicobacter pylori (H. pylori) is a Gram-negative proteobacterium estimated to infect about $50 \%$ of the human population worldwide [1]. Although H. pylori infection remains often asymptomatic [2], it is an important cause of peptic ulcer disease, MALT lymphoma, and gastric cancer [3,4], and H. pylori is the only bacterial pathogen considered as a Class I carcinogen [5]. H. pylori eradication is carried out using either triple or quadruple chemotherapy, in which several antibiotics and antimicrobial compounds including bismuth are combined with a proton pump inhibitor (PPI) [6]. The increasing development of resistance to antimicrobials used in H. pylori eradication therapies has led to the inclusion of clarithromycin (Cla)-resistant $H$. pylori as a Priority 2 pathogen in the WHO global priority pathogens list, urging the development of novel antimicrobials to treat the infection [7]. On the other hand, no specific or highly selective H. pylori antimicrobial exists, which prevents the design of precision eradication therapies that could minimise both the impact on the patients' microbiota and the multiplication of resistances due to the massive use of broad-spectrum antimicrobials [8].

To meet the challenges represented by $H$. pylori eradication, a variety of new targets for pharmacological intervention are being studied [9] including $\mathrm{H}$. pylori flavodoxin ( $\mathrm{Hp}$ Fld) [10]. Flavodoxins are bacterial electron carriers, not present in humans, that participate in different redox reactions and that, depending on the bacteria, may be essential or non-essential proteins $[10,11]$. $H p$-Fld $[12,13]$ is an essential protein that mediates the oxidative decarboxylation of pyruvate by pyruvate-oxidoreductase [14]. It belongs to the long-chain flavodoxin class, differing from short-chain flavodoxins by the presence of an extra loop that may play a role in the binding to partner proteins [15]. While all bacterial flavodoxins, either long or short-chain, are quite similar at the structural level, $\mathrm{Hp}$-Fld contains a distinct pocket near the binding site of the FMN (flavin mononucleotide) redox cofactor [12]. As the binding of small molecules at such a pocket might serve to inhibit electron transfer by the FMN cofactor or to impair the binding of partner proteins to $\mathrm{Hp}$ Fld [11], a high throughput screening was run to identify flavodoxin binders from a diverse chemical library of 10,000 compounds [16]. Furthermore, by using an in vitro coupled reaction, several binders proved to inhibit $\mathrm{Hp}$-Fld activity and, interestingly, they were subsequently shown to be either bactericidal (three of them) or bacteriostatic for H. pylori. After several rounds of chemical variation and efficacy testing [17,18], a family of novel nitrobenzoxadiazol-based antimicrobials has emerged, led by compound IV (Figure 1) [18]. These antimicrobials have been provisionally described as potentially specific for H. pylori, but a detailed analysis of their spectrum of antibacterial activity is lacking. On the other hand, these compounds have been tested in a mouse model of $H$. pylori infection as a monotherapy only [18]. Therefore, further knowledge of the potential synergy of these compounds with compounds currently used in triple/quadruple anti-H. pylori therapies (such as Cla, metronidazole (Mnz), or PPIs) could serve to investigate the efficacy of such novel combination therapies in mice, with the aim of proposing new combination therapies to treat $H$. pylori infections in humans.

In this work, we describe the antimicrobial spectrum of lead compound IV and variants thereof for bacteria belonging to 15 bacterial genera $(7 \mathrm{Gram}$-negatives and $8 \mathrm{Gram}$ positives), including a more detailed characterization of their activity against 9 species of the Helicobacter genus (H. pylori plus 8 non-H. pylori Helicobacter species: NHPH) capable of infecting humans and/or domestic animals and having been described as causative agents of gastric or hepatic pathologies $[19,20]$. Besides, we obtain valuable mechanistic information concerning the binding of the $\mathrm{Hp}$-Fld inhibitors to the target protein and their potential capacity to generate new resistances. As it appears, aniline-bearing IV derivatives are narrow-spectrum antimicrobials specific for H. pylori (and possibly for 
other gastric Helicobacter species), while those bearing a nitro group are extended-spectrum antimicrobials, which are also effective against most Gram-positive bacteria tested.<smiles>COc1ccc(CSc2ccc([N+](=O)[O-])c3nonc23)cc1</smiles><smiles>COc1ccc(CS(=O)c2ccc(N)c3nonc23)cc1</smiles>
IV-d<smiles>COc1ccc(CSc2ccc(N)c3nonc23)cc1</smiles><smiles>O=[N+]([O-])c1ccc(SCc2ccc(OCC(O)CO)cc2)c2nonc12</smiles><smiles>COc1ccc(C2(C)SCc3cc(C)c(C)cc3CS2)cc1</smiles>

IV-b<smiles>Nc1ccc(SCc2ccc(OCC(O)CO)cc2)c2nonc12</smiles>

$r a c-I V-k$<smiles>COc1ccc(CSc2cc(Cl)c(N)c3nonc23)cc1</smiles><smiles>Nc1ccc(S(=O)Cc2ccc(OCC(O)CO)cc2)c2nonc12</smiles>

$r a c-I V-1$

Figure 1. Compounds tested for antimicrobial activity against bacteria.

\section{Materials and Methods}

\subsection{Reagents and Chemicals}

Compounds IV, IV-a, IV-b, IV-c, IV-d (Figure 1) were previously synthesised as described and their $\mathrm{MCC}_{50}$. for eukaryotic cells were determined [18]. The synthesis of compounds rac-IV-j, rac-IV-k and rac-IV-1 is described below. Their $\mathrm{MCC}_{50}$. for eukaryotic cells follow the trends of the respective parent compounds (not shown). The antibiotics metronidazole (Mnz) and clarithromycin (Cla) and the proton pump inhibitors (PPIs) omeprazole and rabeprazole were purchased from Acros Organics, Sigma-Aldrich, Fluorochem and Tokyo Chemical Industry, respectively, whereas the bacterial efflux inhibitors (EIs) carbonyl cyanide 3-chlorophenylhydrazone (CCCP), reserpine and valinomycin were obtained from Sigma-Aldrich. All chemicals were dissolved in 100\% dimethylsulfoxide (DMSO) and stored frozen at $-20^{\circ} \mathrm{C}$. Resazurin sodium salt solution was prepared at $0.01 \%(w / v)$ in distilled water, sterilised by filtering and stored at $4{ }^{\circ} \mathrm{C}$ for up to two weeks. Flavin mononucleotide (FMN) was acquired from Santa Cruz Biotechnology.

\subsection{Synthesis of Compounds Rac-IV-j, Rac-IV-k and Rac-IV-1}

Unless otherwise specified, all reagents for synthesis were obtained from commercial suppliers and were used without purification. TLC was performed on precoated silica gel polyester plates, and products were visualised using UV light (254 nm) and ninhydrin, anisaldehyde, or potassium permanganate solutions, followed by heating. Column chromatography was performed on silica gel $60(70-200 \mu \mathrm{m})$ with air pressure. Melting points were determined in open glass capillaries with a Gallenkamp apparatus. Infrared spectra were recorded with a Fourier transform infrared spectrometer (Thermo Nicolet Avatar 360 FT-IR (Thermo-Fischer Scientific, Waltham, MA, USA)). NMR spectra were recorded with a Bruker AV-400 spectrometer (Bruker-Biospin, Rheinstetten, Germany) (400 MHz for ${ }^{1} \mathrm{H}-\mathrm{NMR}$ experiments and $100 \mathrm{MHz}$ for ${ }^{13} \mathrm{C}-\mathrm{NMR}$ ) or a Bruker AV-300 spectrometer (Bruker-Biospin, Rheinstetten, Germany) (300 MHz for ${ }^{1} \mathrm{H}-\mathrm{NMR}$ experiments) in the stated deuterated solvents. ${ }^{1} \mathrm{H}$ and ${ }^{13} \mathrm{C}$ chemical shifts were referenced to internal solvent resonances and reported in ppm relative to tetramethylsilane. $J$ values are given in Hz. High-resolution positive (or negative) electrospray ionisation mass spectra were recorded with a Bruker Daltonics MicroToF-Q spectrometer (BrukerDaltonics, Billerica, MA, USA) with use of ultradilute solutions of the chemical compounds in methanol. A scheme of the synthesis of compounds rac-IV-j, rac-IV-k and rac-IV-1 is shown in Figure 2. 
<smiles>[CH2+]CC1(C)OCC(CO)O1</smiles><smiles></smiles>

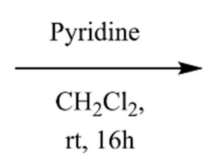<smiles>CC1(C)OCC(CO)O1</smiles>
rac-S1 $(85 \%)$<smiles>CC(C)(C)OCCO</smiles><smiles>CC1(C)OCC(COc2ccc(CO)cc2)O1</smiles>

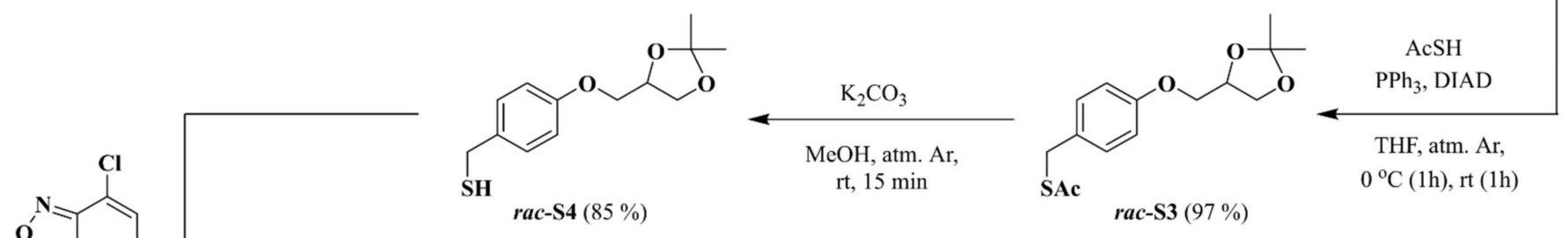

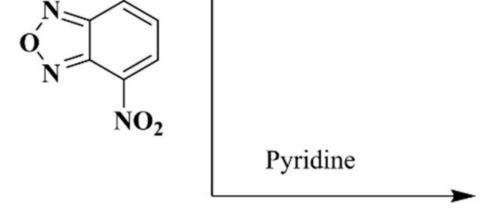

DMF, $80^{\circ} \mathrm{C}$, atm. Ar<smiles>CC1(C)OCC(COc2ccc(CSc3ccc([N+](=O)[O-])c4nonc34)cc2)O1</smiles>

i)Fe, ultrasonic rad. $\mathrm{EtOH} / \mathrm{AcOH} / \mathrm{H}_{2} \mathrm{O}$ $30^{\circ} \mathrm{C}, 30 \mathrm{~min}$

ii) $\mathrm{BiCl}_{3}$ $\mathrm{CH}_{3} \mathrm{CN}, \mathrm{rt}, 16 \mathrm{~h}$<smiles>O=[N+]([O-])c1ccc(SCc2ccc(OCC(O)CO)cc2)c2nc(Cl)nnc12</smiles><smiles></smiles><smiles></smiles>

Figure 2. Scheme of the synthesis of compounds rac-IV-j, rac-IV-k and rac-IV-1.

\subsection{1. rac-(2,2-Dimethyl-1,3-dioxolan-4-yl)methyl p-Toluenenesulfonate (rac-S1)}

A suspension of p-toluenesulfonyl chloride $(1.51 \mathrm{~g}, 7.92 \mathrm{mmol})$ in anhydrous dichloromethane $(3.0 \mathrm{~mL})$ was added dropwise to a solution of (2,2-dimethyl-1,3-dioxolan4-yl)methanol $(872 \mathrm{mg}, 6.60 \mathrm{mmol})$ and pyridine $(1.6 \mathrm{~mL}, 19.8 \mathrm{mmol})$ in anhydrous dichloromethane $(4.0 \mathrm{~mL})$ (Figure 2). The reaction mixture was stirred at room temperature for $16 \mathrm{~h}$. Then, the reaction mixture was washed with water $(10 \mathrm{~mL})$ and the aqueous phase was extracted with dichloromethane $(10 \mathrm{~mL})$. The combined organic layers were dried with anhydrous $\mathrm{MgSO}_{4}$, filtered and evaporated under reduced pressure. The resulting residue was purified by column chromatography (eluent: $\mathrm{Et}_{2} \mathrm{O} /$ hexane 1:1) to afford compound rac-S1 (1.60 g, 85\% yield) as a white solid. mp: $48-49^{\circ} \mathrm{C}$. IR $\left(\mathrm{KBr}, v_{\max } / \mathrm{cm}^{-1}\right): 1169,1347$, 1457, 1495, 1595. ${ }^{1} \mathrm{H}-\mathrm{NMR}\left(300 \mathrm{MHz}, \mathrm{CDCl}_{3}, \delta\right): 7.82-7.74(\mathrm{~m}, 2 \mathrm{H}), 7.38-7.31(\mathrm{~m}, 2 \mathrm{H})$, 4.31-4.22 (m, 1H), 4.06-3.92 (m, 3H), $3.75(\mathrm{dd}, 1 \mathrm{H}, \mathrm{J}=9.0, \mathrm{~J}=5.1), 2.44(\mathrm{~s}, 3 \mathrm{H}), 1.33(\mathrm{~s}, 3 \mathrm{H})$, 1.30 (s, 3H). ${ }^{13} \mathrm{C}-\mathrm{NMR}\left(100 \mathrm{MHz}, \mathrm{CDCl}_{3}, \delta\right): 145.0,132.6,129.9,127.9,110.0,72.9,69.4$, 66.1, 26.6, 25.1, 21.6. HRMS (ESI $\left.{ }^{+}\right): m / z[\mathrm{M}+\mathrm{Na}]^{+}$calculated for $\mathrm{C}_{13} \mathrm{H}_{18} \mathrm{NaO}_{5} \mathrm{~S} 309.0768$, found 309.0754 .

\subsection{2. rac-(4-((2,2-Dimethyl-1,3-dioxolan-4-yl)methoxy)phenyl)methanol (rac-S2)}

To a solution of compound rac-S1 $(802 \mathrm{mg}, 2.80 \mathrm{mmol})$ and 4-hydroxybenzyl alcohol $(417 \mathrm{mg}, 3.36 \mathrm{mmol})$ in anhydrous dimethylformamide $(6.0 \mathrm{~mL})$ was added dry $\mathrm{K}_{2} \mathrm{CO}_{3}$ 
(464 mg, $3.36 \mathrm{mmol}$ ) and the resulting suspension was stirred for $16 \mathrm{~h}$ at $90{ }^{\circ} \mathrm{C}$. The solvent was then removed under reduced pressure and the resulting residue was dissolved in distilled water $(15 \mathrm{~mL})$ and extracted with dichloromethane $(2 \times 10 \mathrm{~mL})$. The combined organic layers were dried with anhydrous $\mathrm{MgSO}_{4}$, filtered and evaporated under reduced pressure. The resulting residue was purified by column chromatography (eluent: $\mathrm{Et}_{2} \mathrm{O} /$ hexane $\left.1: 1\right)$ to afford compound rac-S2 (339 $\mathrm{mg}, 51 \%$ yield) as a white solid. mp: 47-48 ${ }^{\circ} \mathrm{C}$. IR (KBr, $\left.v_{\max } / \mathrm{cm}^{-1}\right)$ : 1453, 1514, 1614, 3402. ${ }^{\mathbf{1}} \mathbf{H}-\mathbf{N M R}\left(300 \mathrm{MHz}, \mathrm{CDCl}_{3}, \delta\right)$ : $7.32-7.25(\mathrm{~m}, 2 \mathrm{H}), 6.93-6.87(\mathrm{~m}, 2 \mathrm{H}), 4.61(\mathrm{~s}, 2 \mathrm{H}), 4.53-4.43(\mathrm{~m}, 1 \mathrm{H}), 4.17(\mathrm{dd}, 1 \mathrm{H}, \mathrm{J}=8.4$, $\mathrm{J}=6.3), 4.06(\mathrm{dd}, 1 \mathrm{H}, \mathrm{J}=9.6, \mathrm{~J}=5.4), 3.94(\mathrm{dd}, 1 \mathrm{H}, \mathrm{J}=9.6, \mathrm{~J}=6.0), 3.90(\mathrm{dd}, 1 \mathrm{H}, \mathrm{J}=8.4$, $\mathrm{J}=5.7), 1.83(\mathrm{sa}, 1 \mathrm{H}), 1.47(\mathrm{~s}, 3 \mathrm{H}), 1.41(\mathrm{~s}, 3 \mathrm{H}) .{ }^{13} \mathrm{C}-\mathrm{NMR}\left(100 \mathrm{MHz}, \mathrm{CDCl}_{3}, \delta\right): 158.1,133.6$, 128.5, 114.5, 109.7, 73.9, 68.8, 66.8, 64.8, 26.7, 25.3. HRMS (ESI $\left.{ }^{+}\right): m / z[M+N a]^{+}$calculated for $\mathrm{C}_{13} \mathrm{H}_{18} \mathrm{NaO}_{4} 261.1098$, found 261.1093.

\subsection{3. rac-S-(4-((2,2-Dimethyl-1,3-dioxolan-4-yl)methoxy)benzyl) Thioacetate (rac-S3)}

To a cooled $\left(0^{\circ} \mathrm{C}\right)$ solution of $\mathrm{PPh}_{3}(671 \mathrm{mg}, 2.56 \mathrm{mmol})$ in anhydrous THF $(8.0 \mathrm{~mL})$ was added diisopropyl azodicarboxylate $(0.50 \mathrm{~mL}, 2.56 \mathrm{mmol})$ and the resulting suspension was stirred for $20 \mathrm{~min}$ at $0^{\circ} \mathrm{C}$ under an argon atmosphere. Then thioacetic acid $(0.18 \mathrm{~mL}$, $2.56 \mathrm{mmol}$ ) and a solution of compound rac-S2 (305 mg, $1.28 \mathrm{mmol})$ in anhydrous THF $(16 \mathrm{~mL})$ were consecutively added. The reaction mixture was stirred under an argon atmosphere for $1 \mathrm{~h}$ at $0{ }^{\circ} \mathrm{C}$ and for 1 additional hour at room temperature. The solvent was removed under reduced pressure and the resulting residue was purified by column chromatography (eluent 1: hexane/ $\mathrm{Et}_{2} \mathrm{O}$ 9:1, eluent 2: hexane $/ \mathrm{Et}_{2} \mathrm{O}$ 8:2) to afford compound rac-S3 (368 $\mathrm{mg}, 97 \%$ yield) as a white solid. $\mathbf{m p}$ : $57-58^{\circ} \mathrm{C}$. IR $\left(\mathrm{KBr}, v_{\max } / \mathrm{cm}^{-1}\right)$ : 1455, 1514, 1612, 1687. ${ }^{1} \mathrm{H}-\mathrm{NMR}\left(300 \mathrm{MHz}, \mathrm{CDCl}_{3}, \delta\right): 7.23-7.16(\mathrm{~m}, 2 \mathrm{H}), 6.87-6.80(\mathrm{~m}, 2 \mathrm{H})$, $4.51-4.40(\mathrm{~m}, 1 \mathrm{H}), 4.15(\mathrm{dd}, 1 \mathrm{H}, \mathrm{J}=8.4, \mathrm{~J}=6.6), 4.07(\mathrm{~s}, 2 \mathrm{H}), 4.03(\mathrm{dd}, 1 \mathrm{H}, \mathrm{J}=9.6, \mathrm{~J}=5.4)$, 3.96-3.83 (m, 2H), 2.33 (s, 3H), $1.45(\mathrm{~s}, 3 \mathrm{H}), 1.40(\mathrm{~s}, 3 \mathrm{H}) .{ }^{13} \mathrm{C}-\mathrm{NMR}\left(100 \mathrm{MHz}, \mathrm{CDCl}_{3}, \delta\right)$ : 195.2, 157.7, 130.1, 129.9, 114.6, 109.7, 73.9, 68.8, 66.8, 32.8, 30.3, 26.7, 25.3. HRMS (ESI ${ }^{+}$): $m / z[\mathrm{M}+\mathrm{Na}]^{+}$calculated for $\mathrm{C}_{15} \mathrm{H}_{20} \mathrm{NaO}_{4} \mathrm{~S} 319.0975$, found 319.0983.

\subsection{4. rac-(4-((2,2-Dimethyl-1,3-dioxolan-4-yl)methoxy)phenyl)methanethiol (rac-S4)}

To a solution of compound rac-S3 (332 $\mathrm{mg}, 1.12 \mathrm{mmol})$ in anhydrous methanol $(15 \mathrm{~mL})$ was added dry $\mathrm{K}_{2} \mathrm{CO}_{3}(185 \mathrm{mg}, 1.34 \mathrm{mmol})$ and the resulting suspension was stirred for $15 \mathrm{~min}$ at room temperature under an argon atmosphere. The reaction mixture was then neutralised by dropwise addition of $2 \mathrm{M} \mathrm{HCl}$ aqueous solution and the solvent was removed under reduced pressure. The resulting residue was dissolved in distilled water $(15 \mathrm{~mL})$ and extracted with dichloromethane $(2 \times 10 \mathrm{~mL})$. The combined organic layers were dried with anhydrous $\mathrm{MgSO}_{4}$, filtered and evaporated under reduced pressure. The resulting residue was purified by column chromatography (eluent: hexane $/ \mathrm{Et}_{2} \mathrm{O} 4: 1$ ) to afford compound rac-S4 (241 mg, 85\% yield) as a white oily solid. mp: $33-34{ }^{\circ} \mathrm{C}$. IR $\left(\mathrm{KBr}, v_{\max } / \mathrm{cm}^{-1}\right): 1456$, 1513, 1611. ${ }^{1} \mathrm{H}-\mathrm{NMR}\left(400 \mathrm{MHz}, \mathrm{CDCl}_{3}, \delta\right): 7.26-7.20(\mathrm{~m}, 2 \mathrm{H}), 6.89-6.82(\mathrm{~m}, 2 \mathrm{H}), 4.51-4.43$ $(\mathrm{m}, 1 \mathrm{H}), 4.16(\mathrm{dd}, 1 \mathrm{H}, \mathrm{J}=8.4, \mathrm{~J}=6.4), 4.04(\mathrm{dd}, 1 \mathrm{H}, \mathrm{J}=9.6, \mathrm{~J}=5.6), 3.92(\mathrm{dd}, 1 \mathrm{H}, \mathrm{J}=9.6$, $\mathrm{J}=6.0), 3.89(\mathrm{dd}, 1 \mathrm{H}, \mathrm{J}=8.4, \mathrm{~J}=5.8), 3.70(\mathrm{~d}, 2 \mathrm{H}, \mathrm{J}=7.6), 1.73(\mathrm{t}, 1 \mathrm{H}, \mathrm{J}=7.6), 1.46(\mathrm{~s}, 3 \mathrm{H})$, 1.40 (s, 3H). ${ }^{13} \mathrm{C}-\mathrm{NMR}\left(100 \mathrm{MHz}, \mathrm{CDCl}_{3}, \delta\right):$ 157.6, 133.7, 129.1, 114.7, 109.7, 73.9, 68.9, 66.8, 28.3, 26.8, 25.3. HRMS (ESI ${ }^{+}$): $m / z[\mathrm{M}+\mathrm{Na}]^{+}$calculated for $\mathrm{C}_{13} \mathrm{H}_{18} \mathrm{NaO}_{3} \mathrm{~S} 277.0870$, found 277.0870 .

\subsection{5. rac-4-((4-((2,2-Dimethyl-1,3-dioxolan-4-yl)methoxy)benzyl)thio)-7- nitrobenzo[c] $[1,2,5]$ oxadiazole (rac-S5)}

To a solution of 4-chloro-7nitrobenzofurazan (285 mg, $1.43 \mathrm{mmol})$ and compound rac-S4 $(242 \mathrm{mg}, 0.95 \mathrm{mmol})$ in anhydrous DMF $(22 \mathrm{~mL})$ was added anhydrous pyridine $(0.15 \mathrm{~mL}, 1.90 \mathrm{mmol})$ and the reaction mixture was stirred for $2 \mathrm{~h}$ at $80^{\circ} \mathrm{C}$ under an argon atmosphere. An extra amount of anhydrous pyridine $(77 \mu \mathrm{L}, 0.95 \mathrm{mmol})$ was then added and the mixture was stirred for 2 additional hours under the same reaction conditions. The solvent was removed under reduced pressure and the resulting residue was purified by 
column chromatography (eluent 1 : hexane $/ \mathrm{Et}_{2} \mathrm{O}$ 7:3, eluent 2: dichloromethane/hexane 9:1; eluent 3: dichloromethane/ $\mathrm{Et}_{2} \mathrm{O}$ 9:1) to afford compound rac-S5 (178 $\mathrm{mg}$, 45\% yield) as a yellow solid. $\mathbf{m p}$ : $106-107{ }^{\circ} \mathrm{C}$. IR $\left(\mathrm{KBr}, v_{\max } / \mathrm{cm}^{-1}\right)$ : $1304,1330,1512 .{ }^{\mathbf{1}} \mathbf{H}-\mathbf{N M R}$ $\left(400 \mathrm{MHz}_{\mathrm{CDCl}}, \delta\right): 8.34(\mathrm{~d}, 1 \mathrm{H}, \mathrm{J}=8.0), 7.38-7.31(\mathrm{~m}, 2 \mathrm{H}), 7.18(\mathrm{~d}, 1 \mathrm{H}, \mathrm{J}=8.0), 6.93-6.86$ $(\mathrm{m}, 2 \mathrm{H}), 4.51-4.43(\mathrm{~m}, 1 \mathrm{H}), 4.47(\mathrm{~s}, 2 \mathrm{H}), 4.16(\mathrm{dd}, 1 \mathrm{H}, \mathrm{J}=8.4, \mathrm{~J}=6.4), 4.04(\mathrm{dd}, 1 \mathrm{H}, \mathrm{J}=9.6$, $\mathrm{J}=5.6), 3.93(\mathrm{dd}, 1 \mathrm{H}, \mathrm{J}=9.6, \mathrm{~J}=5.6), 3.89(\mathrm{dd}, 1 \mathrm{H}, \mathrm{J}=8.4, \mathrm{~J}=5.6), 1.45(\mathrm{~s}, 3 \mathrm{H}), 1.39(\mathrm{~s}, 3 \mathrm{H})$. ${ }^{13} \mathrm{C}-\mathrm{NMR}\left(100 \mathrm{MHz}, \mathrm{CDCl}_{3}, \delta\right): 158.6,149.1,142.4,141.0,132.8,130.6,130.0,125.9,121.3$, 115.1, 109.8, 73.9, 68.8, 66.7, 36.2, 26.8, 25.3. HRMS $\left(\mathbf{E S I}^{+}\right): m / z[\mathrm{M}+\mathrm{Na}]^{+}$calculated for $\mathrm{C}_{19} \mathrm{H}_{19} \mathrm{NaN}_{3} \mathrm{O}_{6} \mathrm{~S} 440.0887$, found 440.0879 .

2.2.6. rac-3-(4-(((7-Nitrobenzo[c] $[1,2,5]$ oxadiazol-4-yl)thio)methyl)phenoxy)propane-1,2diol (rac-IV-j)

Bismuth trichloride (26 mg, $0.082 \mathrm{mmol}$ ) and 7 drops of distilled water were sequentially added to a solution of compound rac-S5 $(171 \mathrm{mg}, 0.41 \mathrm{mmol})$ in acetonitrile $(8.0 \mathrm{~mL})$. The reaction mixture was stirred for $5 \mathrm{~h}$ at room temperature. The solvent was then removed under reduced pressure. The resulting residue was dissolved in $\mathrm{MeOH} / \mathrm{AcOEt}$ 1:1 and adsorbed in silica-gel to be purified by column chromatography (eluent 1: $\mathrm{Et}_{2} \mathrm{O}$, eluent 2: AcOEt), affording compound rac-IV-j (136 mg, 88\% yield) as a yellow solid. mp: $151-152{ }^{\circ} \mathrm{C}$. IR $\left(\mathrm{KBr}, v_{\max } / \mathrm{cm}^{-1}\right)$ : 1304, 1338, 1510, 3289, 3389. ${ }^{\mathbf{1}} \mathrm{H}-\mathrm{NMR}(400 \mathrm{MHz}$, acetone- $\left.\mathrm{d}_{6}, \delta\right): 8.56(\mathrm{~d}, 1 \mathrm{H}, \mathrm{J}=8.0), 7.63(\mathrm{~d}, 1 \mathrm{H}, \mathrm{J}=8.0), 7.52-7.46(\mathrm{~m}, 2 \mathrm{H}), 7.00-6.93(\mathrm{~m}$, $2 \mathrm{H}), 4.66(\mathrm{~s}, 2 \mathrm{H}), 4.14-4.05(\mathrm{~m}, 2 \mathrm{H}), 4.02-3.93(\mathrm{~m}, 2 \mathrm{H}), 3.83-3.77(\mathrm{~m}, 1 \mathrm{H}), 3.71-3.60(\mathrm{~m}, 2 \mathrm{H})$. ${ }^{13} \mathrm{C}-\mathrm{NMR}\left(100 \mathrm{MHz}\right.$, acetone- $\left.\mathrm{d}_{6}, \delta\right): 159.9,150.2,143.8,141.1,132.5,131.3,127.3,123.1$, 115.8, 71.3, 70.4, 64.1, 36.1. HRMS (ESI $\left.{ }^{+}\right): m / z[\mathrm{M}+\mathrm{Na}]^{+}$calculated for $\mathrm{C}_{16} \mathrm{H}_{15} \mathrm{NaN}_{3} \mathrm{O}_{6} \mathrm{~S}$ 400.0574, found 400.0577 .

\subsection{7. rac-3-(4-(((7-Aminobenzo[c][1,2,5]oxadiazol-4-yl)thio)methyl)phenoxy)propane- 1,2-diol (rac-IV-k)}

To a suspension of compound rac-S5 (71 mg, $0.17 \mathrm{mmol})$ in $\mathrm{EtOH} / \mathrm{AcOH} / \mathrm{H}_{2} \mathrm{O}$ 2:2:1 (3.5 $\mathrm{mL})$ was added iron powder $(49 \mathrm{mg}, 0.88 \mathrm{mmol})$ and the reaction mixture was sonicated $(80 \mathrm{~W}, 45 \mathrm{kHz})$ at $30^{\circ} \mathrm{C}$ for $30 \mathrm{~min}$. The reaction mixture was then filtered through a pad of celite ${ }^{\circledR}$ and the filtrate was diluted with dichloromethane $(10 \mathrm{~mL})$ and washed with saturated $\mathrm{K}_{2} \mathrm{CO}_{3}$ aqueous solution $(2 \times 10 \mathrm{~mL})$. The combined aqueous layers were extracted with dichloromethane $(10 \mathrm{~mL})$. The combined organic layers were dried with anhydrous $\mathrm{MgSO}_{4}$, filtered and evaporated under reduced pressure. The resulting crude was used in the next reaction step without further purification. Bismuth trichloride (11 $\mathrm{mg}$, $0.034 \mathrm{mmol}$ ) and 3 drops of distilled water were sequentially added to a solution of the former crude compound in acetonitrile $(3.5 \mathrm{~mL})$. The reaction mixture was stirred for $16 \mathrm{~h}$ at room temperature. The solvent was then removed under reduced pressure. The resulting residue was dissolved in $\mathrm{MeOH} / \mathrm{AcOEt} 1: 1$ and adsorbed in silica-gel to be purified by column chromatography (eluent 1: $\mathrm{Et}_{2} \mathrm{O}$, eluent 2: $\left.\mathrm{Et}_{2} \mathrm{O} / \mathrm{MeOH} 95: 5\right)$, affording compound rac-IV-k (44 mg, 75\% yield) as an orange solid. mp: $161-162{ }^{\circ} \mathrm{C}$. IR $\left(\mathrm{KBr}, v_{\max } / \mathrm{cm}^{-1}\right)$ : 3248, 3358, 3453. ${ }^{1} \mathrm{H}-\mathrm{NMR}\left(400 \mathrm{MHz}, \mathrm{CD}_{3} \mathrm{OD}, \delta\right): 7.08(\mathrm{~d}, 1 \mathrm{H}, \mathrm{J}=7.6), 7.05-6.98(\mathrm{~m}, 2 \mathrm{H})$, 6.81-6.73 (m, 2H), $6.19(\mathrm{~d}, 1 \mathrm{H}, \mathrm{J}=7.6), 4.07(\mathrm{~s}, 2 \mathrm{H}), 4.01-3.96(\mathrm{~m}, 1 \mathrm{H}), 3.96-3.86(\mathrm{~m}, 2 \mathrm{H}), 3.66$ $(\mathrm{dd}, 1 \mathrm{H}, \mathrm{J}=11.2, \mathrm{~J}=4.8), 3.61(\mathrm{dd}, 1 \mathrm{H}, \mathrm{J}=11.2, \mathrm{~J}=5.2) .{ }^{13} \mathrm{C}-\mathrm{NMR}\left(100 \mathrm{MHz}, \mathrm{CD}_{3} \mathrm{OD}, \delta\right)$ : $159.4,152.4,146.5,141.3,138.6,131.6,131.1,115.3,107.0,106.3,71.8,70.3,64.1,39.2$. HRMS $\left(\right.$ ESI $\left.^{+}\right): m / z[\mathrm{M}+\mathrm{Na}]^{+}$calculated for $\mathrm{C}_{16} \mathrm{H}_{17} \mathrm{NaN}_{3} \mathrm{O}_{4} \mathrm{~S} 370.0832$, found 370.0853 .

\subsection{8. rac-3-(4-(((7-Aminobenzo[c][1,2,5]oxadiazol-4- yl)sulfinyl)methyl)phenoxy)propane-1,2-diol (rac-IV-1)}

To a solution of compound rac-IV-k $(24 \mathrm{mg}, 0.07 \mathrm{mmol})$ in glacial acetic acid $(2.0 \mathrm{~mL})$ was added $35 \% \mathrm{H}_{2} \mathrm{O}_{2}$ aqueous solution $(57 \mu \mathrm{L}, 0.59 \mathrm{mmol})$ and the reaction mixture was stirred for $1.5 \mathrm{~h}$ at room temperature. The reaction mixture was quenched with $1 \mathrm{M} \mathrm{Na}_{2} \mathrm{SO}_{3}$ aqueous solution $(0.59 \mathrm{~mL}, 0.59 \mathrm{mmol})$ and the resulting suspension was diluted with distilled water and extracted with ethyl acetate $(4 \times 10 \mathrm{~mL})$. The combined organic layers were dried with anhydrous $\mathrm{MgSO}_{4}$, filtered and evaporated under reduced pressure. The 
resulting residue was dissolved in methanol and adsorbed in silica-gel to be purified by column chromatography (eluent 1: AcOEt, eluent 2: $\mathrm{Et}_{2} \mathrm{O} / \mathrm{MeOH}$ 9:1), affording compound rac-IV-1 (21 mg, $82 \%$ yield) as a yellow solid. $\mathrm{mp}: 73-74{ }^{\circ} \mathrm{C}$. IR $\left(\mathrm{KBr}, v_{\max } / \mathrm{cm}^{-1}\right): 1032$, 3405. ${ }^{1} \mathrm{H}-\mathrm{NMR}\left(400 \mathrm{MHz}, \mathrm{CD}_{3} \mathrm{OD}, \delta\right): 7.39(\mathrm{~d}, 1 \mathrm{H}, \mathrm{J}=7.6), 6.99-6.92(\mathrm{~m}, 2 \mathrm{H}), 6.85-6.78$ $(\mathrm{m}, 2 \mathrm{H}), 6.31(\mathrm{~d}, 1 \mathrm{H}, \mathrm{J}=7.6), 4.54(\mathrm{~d}, 1 \mathrm{H}, \mathrm{J}=13.0), 4.39(\mathrm{~d}, 1 \mathrm{H}, \mathrm{J}=13.0), 4.03-3.96(\mathrm{~m}$, 1H), 3.96-3.87 (m, 2H), 3.70-3.58 (m, 2H). ${ }^{13} \mathrm{C}-\mathrm{NMR}\left(100 \mathrm{MHz}, \mathrm{CD}_{3} \mathrm{OD}, 8\right): 160.6,147.3$, 146.1, 142.9, 138.1, 132.6, 122.9, 115.6, 111.8, 104.1, 71.7, 70.3, 64.1, 59.4. HRMS (ESI $\left.{ }^{+}\right): m / z$ $[\mathrm{M}+\mathrm{Na}]^{+}$calculated for $\mathrm{C}_{16} \mathrm{H}_{17} \mathrm{NaN}_{3} \mathrm{O}_{5} \mathrm{~S} 386.0781$, found 386.0779.

\subsection{Bacterial Strains, Culture Media and Growth Conditions}

H. pylori (ATCC 700392) and Helicobacter hepaticus (ATCC 51449) were purchased from the American Type Culture Collection (ATCC, Manassas, VA, USA), whereas Campylobacter jejuni (ATCC 33560) was donated by Dr. Pilar Mañas from the University of Zaragoza (Spain). Strains of Helicobacter felis (JKM5), Helicobacter suis (HS1 and HS5), Helicobacter heilmannii (ASB1.4 and ASB2), Helicobacter ailurogastricus (ASB7 and ASB9) and Helicobacter bizzozeronii (ASB22 kol15) have been described in Smet et al. [21]. Strains of H. bizzozeronii (10 and Heydar) were provided by Prof. Dr. Mirko Rossi. Helicobacter muridarum and Helicobacter bilis were available from Dr. Eliette Touati from the Institut Pasteur (Paris, France). Salmonella enterica subsp. enterica serovar Typhimurium (S. Typhimurium; SV 5015), Escherichia coli (ATCC 10536), Pseudomonas aeruginosa (ATCC 15442), Bacillus sp. (CECT 40), Streptococcus pneumoniae (ATCC 49619), Listeria monocytogenes (ATCC BAA-679), Enterococcus faecalis (JH2-2), Corynebacterium diphtheriae (ATCC 39255), Corynebacterium ammoniagenes (ATCC 6872), Mycolicibacterium smegmatis (ATCC 700084) and Staphylococcus aureus (ATCC 29213) were available from the culture collections of the Departments of Microbiology and Biochemistry of the University of Zaragoza (Spain).

The strains P. aeruginosa MPAO1 and P. aeruginosa PW9682, a $\Delta r m l C$ mutant of MPAO1 that is defective in lipopolysaccharide (LPS) biosynthesis [22], were obtained from the Transposon Mutant Collection of the University of Washington [23,24]. Klebsiella pneumoniae subspecies pneumoniae strains 3025 (serotype O1: $\mathrm{K}^{-}, \mathrm{Str}^{\mathrm{R}}$; produces smooth-type LPS with D-galactan I and D-galactan II O-antigens) and CWK43 (rpsL, cps, rfb, $\mathrm{Str}^{\mathrm{R}}$, serotype $\mathrm{O}^{-}: \mathrm{K}^{-}$; produces truncated rough-type LPS) [25-27] were kindly provided by Prof. Dr. Ian R. Poxton (Department of Medical Microbiology, University of Edinburgh, Edinburgh, U.K.) and Prof. Dr. Chris Whitfield (Department of Molecular and Cellular Biology, University of Guelph, Guelph, ON, Canada), respectively. The Stenotrophomonas maltophilia K279a [28] wild-type strain was originally obtained from the laboratory of Prof. Dr. Matthew B. Avison (School of Medical Sciences, University of Bristol, Bristol, U.K.), and the construction of the S. maltophilia K279a $\triangle r m l B A C D$ [29] mutant lacking the O-antigen of LPS has been described elsewhere.

Cultures of H. pylori, H. hepaticus, H. muridarum and H. bilis were grown in blood agar base No. 2 (Oxoid, Basingstoke, Hampshire, UK) supplemented with $8 \%$ defibrinated horse blood (Oxoid) under microaerophilic conditions $\left(85 \% \mathrm{~N}_{2}, 10 \% \mathrm{CO}_{2}, 5 \% \mathrm{O}_{2}\right)$ at $37{ }^{\circ} \mathrm{C}$ for 48-72 h. For drug susceptibility testing, bacteria were grown under the same conditions in brain heart infusion (BHI) broth (Oxoid) supplemented with $4 \%$ foetal bovine serum (FBS) (Pan-Biotech, Aidenbach, Germany) for H. pylori, 10\% FBS and $2.5 \mathrm{~g} / \mathrm{L}$ yeast extract (Scharlab, Barcelona, Spain) for H. hepaticus, and 10\% FBS for H. muridarum and H. bilis. In these last two cases, the cultures were also stirred at $150 \mathrm{rpm}$. Cultures of $C$. jejuni were grown under the same conditions except for the FBS supplement and shaking. Susceptibility of $\mathrm{H}$. felis and $\mathrm{H}$. bizzozeronii to the compounds was evaluated by incubating bacteria on Mueller-Hinton II agar (Becton Dickinson, Cockeysville, MD, USA), supplemented with $10 \%$ defibrinated horse blood and $0.6 \%$ Vitox (Oxoid) for 7 days at $37{ }^{\circ} \mathrm{C}$ under microaerophilic conditions. H. suis, H. heilmannii and H. ailurogastricus were grown for $48 \mathrm{~h}$ at $\mathrm{pH} 5$ and $37^{\circ} \mathrm{C}$ under microaerophilic conditions, using a biphasic medium consisting of Brucella agar (BD, Franklin Lakes, NJ, USA) supplemented with 20\% inactivated fetal calf serum (Hyclone, ThermoFisher Scientific, Waltham, MA, USA), Vitox supplement 
(Oxoid), and Campylobacter selective supplement (Skirrow, Oxoid), with Brucella broth (Oxoid) added on top. On the other hand, S. Typhimurium, E. coli, P. aeruginosa, Bacillus sp. and E. faecalis were grown under aerobic conditions at $37^{\circ} \mathrm{C}$ in lysogeny broth (LB) overnight with stirring at $150 \mathrm{rpm}$. Same conditions were used for M. smegmatis cultures, but it was incubated for $72 \mathrm{~h}$ without shaking. Cultures of L. monocytogenes, C. diphtheriae and $C$. ammoniagenes were grown in BHI broth for $24 \mathrm{~h}$ with stirring at $150 \mathrm{rpm}$, with the exception of the last one whose culture was incubated overnight. S. pneumoniae was grown in BHI broth supplemented with $4 \%$ FBS for $10 \mathrm{~h}$, while $S$. aureus was cultured in Mueller-Hinton broth (Panreac, Castellar del Vallès, Spain) pH 7 for $16 \mathrm{~h}$. Finally, the strains 3025 and CWK43 of K. pneumoniae, K279a and K279a $\triangle$ rmlBACD of S. maltophilia, and MPAO1 of $P$. aeruginosa were routinely grown with shaking $(220 \mathrm{rpm})$ at $37^{\circ} \mathrm{C}$ in LB medium. For cultivation of P. aeruginosa PW9682, the LB medium was supplemented $17 \mu \mathrm{g} / \mathrm{mL}$ of tetracycline.

\subsection{Evaluation of the Antibacterial Activity against a Diverse Microbial Panel}

Serial broth microdilutions were made to determine the Minimal Inhibitory Concentration (MIC) of IV, IV-a, IV-b, IV-c, IV-d, rac-IV-j, rac-IV-k, rac-IV-1, Mnz and Cla against $H$. pylori, H. hepaticus, H. muridarum, H. bilis, C. jejuni, S. Typhimurium, E. coli, $P$. aeruginosa, Bacillus sp., S. pneumoniae, L. monocytogenes, E. faecalis, S. aureus, C. diphtheriae, C. ammoniagenes and M. smegmatis as previously described [18]. Briefly, each well of a 96-well plate was inoculated with $100 \mu \mathrm{L}$ of fresh liquid bacterial culture at $10^{6} \mathrm{CFU} / \mathrm{mL}$ (for Helicobacter strains) or $5 \times 10^{5} \mathrm{CFU} / \mathrm{mL}$ (for the other bacteria), except for the first well of each raw, which received $200 \mu \mathrm{L}$ of bacterial culture plus $2 \mu \mathrm{L}$ of compound (from stock solutions at $6.4 \mathrm{mg} / \mathrm{mL}$ in $100 \% \mathrm{DMSO}$ ). After performing two-fold serial dilutions, plates were incubated under the culture conditions described above, to evaluate the antimicrobial activity of compounds in a concentration range of $0.031-64 \mu \mathrm{g} / \mathrm{mL}$. MIC values, defined as the lowest concentration of compound able to inhibit bacterial growth, were determined after addition of $30 \mu \mathrm{L}$ of resazurin $0.1 \mathrm{mg} / \mathrm{mL}$ (Sigma-Aldrich, San Luis, MO, USA). Positive and negative controls were included in all the experiments, which were performed, at least, twice in duplicate. MIC values of omeprazole, rabeprazole, CCCP, reserpine and valinomycin against $H$. pylori (ATCC 700392) were also determined by the microdilution MIC testing as explained above.

Susceptibility of $H$. felis and H. bizzozeronii to compounds IV and rac-IV-j was evaluated by the agar dilution method, as previously described [30]. Succinctly, compounds were added to agar plates according to two-fold serial dilutions, with final concentrations ranging from 0.03 to $128 \mu \mathrm{g} / \mathrm{mL}$. Agar plates free of compounds were included as positive controls. H. felis and H. bizzozeronii bacteria were grown for $72 \mathrm{~h}$, then harvested and suspended in sterile saline to a density of 3 on the McFarland turbidity scale. Then, plates were seeded by a Steers inoculum replicator (MAST, London, United Kingdom) and incubated in a microaerophilic atmosphere. After 7 days, plates were read, the MIC being determined as the lowest compound concentration that inhibits visible growth. MICs of IV and rac-IV-j against $H$. suis, $H$. heilmannii and $H$. ailurogastricus were determined by using a combined agar and broth dilution method in 24-well plates (Greiner Bio-On, Frickenhausen, Germany), as previously described [31]. In brief, agar plates and broth were prepared to contain two-fold serial dilutions of the tested compounds. Then, they were inoculated with $150 \mu \mathrm{L}$ of the bacterial culture at $5 \times 10^{7}$ bacteria $/ \mathrm{mL}$, so that each well of the 24-well plates contained $200 \mu \mathrm{L}$ of broth and $400 \mu \mathrm{L}$ agar, with final concentrations of the compounds ranging from 0.03 to $128 \mu \mathrm{g} / \mathrm{mL}$. Wells containing only bacterial culture were included as positive controls. MICs were determined as the lowest compound concentration with at least $50 \%$ bacterial growth inhibition compared to controls. To determine the impact of culture and $\mathrm{pH}$ conditions on the activity of the compounds IV and rac-IV-j, 2 different MIC assays were performed for S. aureus: (i) the combined agar and broth dilution method at $\mathrm{pH} 5$, similar to the described above and (ii) the broth microdilution method (according to the Clinical and Laboratory Standards Institute ([32]) standards) 
in unsupplemented Mueller Hinton broth at $\mathrm{pH} 7$, as previously reported [31]. In both cases, bacterial growth was analysed after $16-24 \mathrm{~h}$ of incubation. The MIC was recorded as the lowest compound concentration for which there was no turbidity. Susceptibility of $P$. aeruginosa strains MPAO1 and PW9682, S. maltophilia strains K279a and K279a $\triangle r m l B A C D$, as well as K. pneumoniae 3025 and CWK43 to IV, IV-a, IV-b, IV-c and IV-d was studied by MIC determination using the broth microdilution method in LB medium essentially as described above, except that each culture with a starting $\mathrm{OD}_{600}$ of 0.01 was mixed with a two-fold serial dilution of each compound in a concentration range between 0.25 and $512 \mu \mathrm{g} / \mathrm{mL}$. The microtiter plates were incubated at $37^{\circ} \mathrm{C}$ in a humidified chamber for $20 \mathrm{~h}$, followed by determination of the $\mathrm{OD}_{600}$ values and incubation of the cultures in the presence of resazurin at $37^{\circ} \mathrm{C}$ for $30 \mathrm{~min}$.

\subsection{Cloning, Expression, Purification and Quantification of Recombinant Flavodoxin}

Recombinant wild-type Hp-Fld, along with N14A, A55W, V113W, Q115W, T116W, K133A and D142Y mutants, were overexpressed in E. coli strain BL21 (DE3, Sigma-Aldrich) and purified as previously described [11] with slight modifications. A bacterial culture containing the pET28a-fldA plasmid was grown at $37^{\circ} \mathrm{C}$ in LB medium supplemented with $20 \mu \mathrm{g} / \mathrm{mL}$ kanamycin (Sigma-Aldrich) to an $\mathrm{OD}_{600}$ of 0.8. Then, flavodoxin expression was induced by addition of $1 \mathrm{mM}$ isopropyl $\beta$-D-thiogalactoside (Thermo Fisher Scientific) and further incubation at $37^{\circ} \mathrm{C}$ overnight. After centrifugation, bacteria were resuspended in cell disruption buffer (50 mM Tris-HCl buffer, $100 \mu \mathrm{M}$ EDTA, $100 \mu \mathrm{M} \beta$-mercaptoethanol and $1 \mu \mathrm{M}$ phenylmethanesulphonyl fluoride, $\mathrm{pH}$ 8), mixed with $50 \mathrm{mg}$ of FMN (Santa Cruz Biotechnology, Dallas, TX, USA) and lysed by sonication (Hielscher UP200S, $24 \mathrm{kHz}$ ). After centrifugation at $18.000 \mathrm{rpm}$ (in an Avanti J-26XP High Performance Centrifuge (Beckman Coulter, Brea, CA, USA) with a JA-25.50 rotor) for 30 min at $4{ }^{\circ} \mathrm{C}$, the supernatant was precipitated with $65 \%\left(\mathrm{NH}_{4}\right)_{2} \mathrm{SO}_{4}$ and centrifuged at $18.000 \mathrm{rpm}$ for $30 \mathrm{~min}$ at $4{ }^{\circ} \mathrm{C}$. The supernatant was then loaded onto a diethylaminoethyl (DEAE) cellulose column equilibrated with $65 \%\left(\mathrm{NH}_{4}\right)_{2} \mathrm{SO}_{4}$ in $50 \mathrm{mM}$ Tris- $\mathrm{HCl}$ buffer, $\mathrm{pH} 8$, and the flavodoxin, which is only weakly bound to the column, was eluted with $65 \%\left(\mathrm{NH}_{4}\right)_{2} \mathrm{SO}_{4}$ in $50 \mathrm{mM}$ Tris- $\mathrm{HCl}$ buffer, $\mathrm{pH} 8$ and then dialysed. The eluted fractions were poured onto a DEAE column equilibrated with $50 \mathrm{mM}$ Tris- $\mathrm{HCl}$ buffer, $\mathrm{pH} 8$ and the protein was eluted with a linear gradient from 0 to $1 \mathrm{M} \mathrm{NaCl}$ in $50 \mathrm{mM}$ Tris- $\mathrm{HCl}$ buffer, $\mathrm{pH}$ 8. Then, it was dialysed against the corresponding buffer, concentrated, transformed into holoprotein if needed, and quantified by using the theoretical extinction coefficients $\left(\varepsilon_{\mathrm{APO}}, 278 \mathrm{~nm}=15.96 \mathrm{mM}^{-1} \mathrm{~cm}^{-1}\right.$; $\left.\varepsilon_{\mathrm{HOLO}, 278 \mathrm{~nm}}=37.37 \mathrm{mM}^{-1} \mathrm{~cm}^{-1} ; \varepsilon_{\mathrm{HOLO}}, 452 \mathrm{~nm}=10.65 \mathrm{mM}^{-1} \mathrm{~cm}^{-1}\right)$. Flavodoxin purity was determined by $15 \%$ SDS-PAGE, followed by Coomassie staining (Figure S1). The native conformation of wild type and of the flavodoxin variants can be inferred from the corresponding visible spectra (Figure S2) as, in all variants, the distinctive flavin absorption shoulder at $480 \mathrm{~nm}$, characteristic of FMN bound to native flavodoxin, is clearly observed [33].

\subsection{Determination of the Hp-Fld-Binding Affinity of Inhibitors}

Isothermal titration calorimetry (ITC) experiments were carried out in an Auto-iTC200 calorimeter (MicroCal, Malvern-Panalytical, Malvern, UK) in order to characterise the affinity of the wild-type $\mathrm{Hp}$-Fld protein and the different mutants N14A, A55W, V113W, Q115W, T116W, K133A and D142Y for the different compounds. Recombinant Hp-Fld at 10-20 $\mu \mathrm{M}$ concentration in $50 \mathrm{mM}$ EPPS buffer, $\mathrm{pH} 9$ (for IV, IV-a, IV-b, IV-c, racIV-j, rac-IV-k and rac-IV-1), or in $50 \mathrm{mM}$ Tris- $\mathrm{HCl}$ buffer, $\mathrm{pH} 9$ (for IV-d) was titrated with 120-300 $\mu \mathrm{M}$ ligand solutions in the same buffer, prepared from stock compound solutions in $100 \%$ DMSO. At the residual DMSO concentration of $2.5 \%$ employed in the working solutions, wild-type flavodoxin has been described to be conformationally stable and biochemically active [16]. Thermodynamic parameters of the binding equilibrium were calculated by non-linear least-squares regression analysis considering a single ligand 
binding site and using the user-defined fitting routines in the MicroCal LLC ITC module from the Origin 7.0 software (Northampton, MA, USA).

\subsection{Molecular Docking of Compounds IV, IV-a, IV-b, IV-c and IV-d to Hp-Fld}

Initial structures of compounds IV, IV-a, IV-b, IV-c and IV-d were obtained from their SMILES codes through the online NCI/CADD SMILES translator tool (https:/ / cactus. nci.nih.gov/translate/ (accessed on 10 September 2020), NIH National Cancer Institute, Frederick, MD, USA). They were subsequently optimised at the ab initio level (\#HF/6-31G*) with Gaussian 09 [34], and the resulting structures were docked onto the three-dimensional structure of wild-type Hp-Fld (PDB ID: 1FUE) with AutoDock4.2.6 (La Jolla, CA, USA) [35]. A first round of docking was performed, allowing the compounds to sample the whole protein surface (blind docking), keeping the protein rigid and allowing the compounds' rotatable bonds to freely rotate. The flavodoxin regions, which showed the highest scored poses of docked compounds, were then subjected to targeted docking (local sampling), now with both entities in flexible mode (protein sidechains' and compounds' rotatable bonds allowed to rotate). The amino acid residues that appeared crucial for the binding were identified. They were replaced by site directed mutagenesis for the sake of testing their potential contribution to complex formation with the inhibitory compounds by ITC. To that end, the affinity of the complexes formed by the chosen compounds and wild-type $\mathrm{Hp}$-Fld was compared to that of the complexes established with the mutant flavodoxins.

\subsection{Combined Antimicrobial Effect}

Once the MICs of EIs CCCP, reserpine and valinomycin against $H$. pylori were determined, as described above, the antimicrobial effect of several IV-related compounds was evaluated in combination with these EIs. To that end, the MIC of each compound against a H. pylori culture was evaluated in the presence of each EI at a concentration of $\frac{1}{4}$ of its MIC. The assay was carried out in the same way as a conventional microdilution MIC testing, and the culture conditions were as described above. We considered that any EI had a significant effect on a compound MIC when this was reduced at least four-fold in the presence of that EI. Each experiment was performed twice in triplicate.

\subsection{Generation of Spontaneous Resistant Mutants}

H. pylori reference strain ATCC 700392, at $5 \times 10^{6}$ and $5 \times 10^{7} \mathrm{CFU} / \mathrm{mL}$ in BHI broth (Oxoid) supplemented with $4 \%$ FBS, was incubated at $37^{\circ} \mathrm{C}$ for 5 days under microaerophilic conditions in the presence of compounds IV, IV-d and rac-IV-1 at final concentrations of 32, 16, 8, 4, 2, 1 and 0.5 times their MICs. Because H. pylori is able to develop resistance to $\mathbf{M n z}$, this antibiotic was used as a control. The generation of resistant mutants was evaluated by the MIC values of compounds IV, IV-a, IV-c, IV-d, rac-IV-1 and Mnz against the treated cultures, compared to the corresponding MIC of the parental wild-type strain. The experiment was performed twice in duplicate.

\subsection{Chequerboard Synergy Testing}

Pairwise interactions between several IV-related compounds and Mnz, Cla, omeprazole or rabeprazole, as well as between parent compound IV and its derivatives IV-a, IV-b, IV-c, IV-d, rac-IV-j, rac-IV-k and rac-IV-1 were studied in H. pylori strain ATCC 700392. In a 96-well plate containing a fresh culture of bacteria at $10^{6} \mathrm{CFU} / \mathrm{mL}$, one compound (at 32 times its MIC) was added to the second column and the other one (at 4 times its MIC) was poured in raw G. Both compounds were serially 2 -fold diluted to generate a gradient matrix of both compounds. The first and last columns of the plate allowed one to test each compound alone. After incubation as described above for H. pylori growth, plates were treated with resazurin, as in a conventional MIC assay, to reveal the result of the interaction effect. For each pair of compounds, the fractional inhibitory concentration index $(\mathrm{FICI})$ was determined as $\mathrm{FICI}=\mathrm{FIC}_{1}+\mathrm{FIC}_{2}$, where $\mathrm{FIC}_{1}=\left(\mathrm{MIC}_{\text {compound } 1}\right.$ in presence of compound 2$) /\left(\mathrm{MIC}_{\text {compound } 1}\right.$ alone $)$ and $\mathrm{FIC}_{2}=\left(\mathrm{MIC}_{\text {compound } 2}\right.$ in presence 
of compound 1)/( $\mathrm{MIC}_{\text {compound } 2}$ alone). The value of the FICI indicates whether two compounds show a synergistic effect $(\mathrm{FICI} \leq 0.5)$, no interaction $(0.5<\mathrm{FICI} \leq 4)$ or an antagonistic effect (FICI > 4) effect [36]. Pairs of FIC values can be represented graphically, and a concave curve indicating synergy. The point of the curve closest to the intersection of the axes corresponds to the most effective combination of compounds that inhibits $H$. pylori growth $[37,38]$.

\section{Results}

\subsection{Selectivity of the Flavodoxin Inhibitors for Bacteria of the Helicobacter Genus}

The in vitro efficacy of IV-related compounds, Mnz and Cla, was evaluated (Table 1) against several bacteria from different phyla (Table S2). Their therapeutic activity was reported as the lowest concentration, leading to $50 \%$ bacterial growth inhibition in comparison with drug-free controls (for the Helicobacter species requiring a biphasic growth medium) or as the MIC (for the other bacteria tested in broth). As seen in Table 1, while H. pylori is susceptible to all IV-related compounds (except rac-IV-1) at low concentrations, the growth of many other bacteria tested is not inhibited by most of these derivatives even at concentrations up to 64 or $512 \mu \mathrm{g} / \mathrm{mL}$, respectively. However, according to MIC breakpoints of antibiotics traditionally used to treat these bacterial infections [39], two compounds, IV and rac-IV-j, show moderate to good antimicrobial activity $(\leq 32 \mu \mathrm{g} / \mathrm{mL})$ against C. jejuni, and the Gram-positive Bacillus sp., S. pneumoniae, E. faecalis, S. aureus, C. diphtheriae and C. ammoniagenes. Moreover, these compounds show low MICs for the gastric non-H. pylori Helicobacter species tested (H. felis, H. suis, H. heilmannii, H. ailurogastricus and H. bizzozeronii) and against the enterohepatic Helicobacter species H. muridarum and H. bilis.

Globally, the effect of the compounds can be described considering three groups of bacteria: Gram-positive, the Gram-negative bacteria belonging to the Helicobacter and Campylobacter genera, and all other Gram-negative ones. The growth of most Gram-positive bacteria tested-except $M$. smegmatis and L. monocytogenes - is inhibited by compounds IV and rac-IV-j but not by compounds IV-a, IV-b, IV-c, IV-d, rac-IV-k or rac-IV-1.

Table 1. In vitro activity of IV-related compounds against several bacteria from different phyla.

\begin{tabular}{|c|c|c|c|c|c|c|c|c|c|c|c|}
\hline \multirow[b]{2}{*}{ Gram } & \multirow[b]{2}{*}{ Bacterial Species (Strain) } & \multicolumn{10}{|c|}{ Compound MIC ( $\mu \mathrm{g} / \mathrm{mL})$} \\
\hline & & IV & IV-a & IV-b & IV-c & IV-d & $\begin{array}{l}\text { rac- } \\
\text { IV-j }\end{array}$ & $\begin{array}{l}\text { rac- } \\
\text { IV-k }\end{array}$ & rac-IV-1 & Mnz & Cla \\
\hline- & $\begin{array}{c}\text { H. pylori } \\
(\text { ATCC 700392) * }\end{array}$ & 2 & 8 & 1 & 2 & 8 & 1 & 16 & 256 & 2 & $\leq 0.032$ \\
\hline- & $\begin{array}{l}\text { H. felis } \\
\text { (JKM5) }\end{array}$ & 8 & & & & & 32 & & & & $\leq 0.031$ \\
\hline- & $\begin{array}{l}\text { H. suis } \\
\text { (HS1) }\end{array}$ & 4 & & & & & 4 & & & & 0.25 \\
\hline & (HS5) & 4 & & & & & 2 & & & & $\leq 0.031$ \\
\hline- & $\begin{array}{l}\text { H. heilmannii } \\
\text { (ASB1.4) }\end{array}$ & 2 & & & & & 2 & & & & 0.125 \\
\hline & (ASB2) & 2 & & & & & 1 & & & & $\leq 0.031$ \\
\hline- & $\begin{array}{l}\text { H. ailurogastricus } \\
\text { (ASB7) }\end{array}$ & 4 & & & & & 1 & & & & 0.125 \\
\hline & (ASB9) & 4 & & & & & 4 & & & & 0.5 \\
\hline- & $\begin{array}{l}\text { H. bizzozeronii } \\
\text { (ASB22 kol15) }\end{array}$ & 16 & & & & & 16 & & & & $\leq 0.031$ \\
\hline & (10) & 8 & & & & & 32 & & & & $\leq 0.031$ \\
\hline & (Heydar) & 8 & & & & & 32 & & & & $\leq 0.031$ \\
\hline- & $\begin{array}{c}\text { H. hepaticus } \\
\text { (ATCC } 51449 / 3 \mathrm{~B} 1 \text { ) }\end{array}$ & 64 & $>64$ & $>64$ & $>64$ & $>64$ & 64 & $>64$ & $>64$ & $>64$ & 0.063 \\
\hline- & H. muridarum & 1 & $>64$ & $>64$ & $>64$ & $>64$ & 4 & $>64$ & $>64$ & $>64$ & $>64$ \\
\hline- & H. bilis & 16 & $>64$ & $>64$ & $>64$ & $>64$ & 16 & $>64$ & $>64$ & $>64$ & 4 \\
\hline- & $\begin{array}{c}\text { C. jejuni } \\
(\text { ATCC 33560) * }\end{array}$ & 2 & $>64$ & $>64$ & $>64$ & $>64$ & 4 & $>64$ & $>64$ & 1 & 4 \\
\hline- & $\begin{array}{l}\text { S. Typhimurium } \\
\text { (SV 5015)* }\end{array}$ & $>64$ & $>64$ & $>64$ & $>64$ & $>64$ & $>64$ & $>64$ & $>64$ & $>64$ & $>64$ \\
\hline
\end{tabular}


Table 1. Cont.

\begin{tabular}{|c|c|c|c|c|c|c|c|c|c|c|c|}
\hline \multirow{2}{*}{ Gram } & \multirow{2}{*}{ Bacterial Species (Strain) } & \multicolumn{10}{|c|}{ Compound MIC $(\mu \mathrm{g} / \mathrm{mL})$} \\
\hline & & IV & IV-a & IV-b & IV-c & IV-d & $\begin{array}{l}\text { rac- } \\
\text { IV-j }\end{array}$ & $\begin{array}{l}\text { rac- } \\
\text { IV-k }\end{array}$ & rac-IV-1 & Mnz & Cla \\
\hline- & $\begin{array}{c}\text { E. coli } \\
\text { (ATCC 10536) * }\end{array}$ & $>64$ & $>64$ & $>64$ & $>64$ & $>64$ & $>64$ & $>64$ & $>64$ & $>64$ & 16 \\
\hline- & $\begin{array}{l}\text { P. aeruginosa } \\
\text { (ATCC 15442) }\end{array}$ & $>64$ & $>64$ & $>64$ & $>64$ & $>64$ & $>64$ & $>64$ & $>64$ & $>64$ & 8 \\
\hline & $\begin{array}{l}\text { (MPAO1) } \\
\text { (PW9682) }\end{array}$ & $\begin{array}{l}>512 \\
>512\end{array}$ & $\begin{array}{l}>512 \\
>512\end{array}$ & $\begin{array}{l}>512 \\
>512\end{array}$ & $\begin{array}{l}>512 \\
>512\end{array}$ & $\begin{array}{l}>512 \\
>512\end{array}$ & & & & & \\
\hline- & $\begin{array}{l}\text { S. maltophilia } \\
\mathrm{K} 279 \mathrm{a}\end{array}$ & $>512$ & $>512$ & $>512$ & $>512$ & $>512$ & & & & & \\
\hline & $(\mathrm{K} 279 \mathrm{a} \triangle \mathrm{rmlBACD})$ & $>512$ & $>512$ & $>512$ & $>512$ & $>512$ & & & & & \\
\hline- & $\begin{array}{c}\text { K. pneumoniae } \\
3025\end{array}$ & $>512$ & $>512$ & $>512$ & $>512$ & $>512$ & & & & & \\
\hline & (CWK43) & $>512$ & $>512$ & $>512$ & $>512$ & $>512$ & & & & & \\
\hline+ & $\begin{array}{l}\text { Bacillus sp. } \\
\text { (CECT 40) }\end{array}$ & 4 & $>64$ & $>64$ & $>64$ & $>64$ & 4 & $>64$ & $>64$ & $>64$ & 0.063 \\
\hline+ & $\begin{array}{l}\text { S. pneumoniae } \\
\text { (ATCC 49619) }\end{array}$ & 8 & $>64$ & $>64$ & 64 & $>64$ & 16 & $>64$ & $>64$ & $>64$ & $\leq 0.032$ \\
\hline+ & $\begin{array}{l}\text { L. monocytogenes } \\
\text { (ATCCBAA-679) }\end{array}$ & $>64$ & $>64$ & $>64$ & $>64$ & $>64$ & $>64$ & $>64$ & $>64$ & $>64$ & 0.25 \\
\hline+ & $\begin{array}{l}\text { E. faecalis } \\
\text { (JH2-2) }\end{array}$ & 2 & $>64$ & $>64$ & $>64$ & $>64$ & 4 & $>64$ & $>64$ & $>64$ & 0.25 \\
\hline+ & $\begin{array}{c}\text { S. aureus } \\
\text { (ATCC 29213) }\end{array}$ & 16 & $>64$ & $>64$ & $>64$ & $>64$ & 8 & $>64$ & $>64$ & $>64$ & $\leq 0.032$ \\
\hline & BB pH 5 & 16 & & & & & $16-64$ & & & & $8-16$ \\
\hline & $\mathrm{MH}$ broth $\mathrm{pH} 7$ & 16 & & & & & 16 & & & & $0.5-1$ \\
\hline+ & $\begin{array}{l}\text { C. diphtheriae } \\
\text { (ATCC 39255) }\end{array}$ & 16 & 64 & $>64$ & 8 & $>64$ & 32 & $>64$ & $>64$ & $>64$ & 0.063 \\
\hline+ & $\begin{array}{l}\text { C. ammoniagenes } \\
\text { (ATCC 7862) }\end{array}$ & 16 & $>64$ & $>64$ & $>64$ & $>64$ & 16 & $>64$ & $>64$ & $>64$ & $\leq 0.032$ \\
\hline+ & $\begin{array}{l}\text { M. smegmatis } \\
\text { (ATCC 700084) }\end{array}$ & $>64$ & $>64$ & $>64$ & $>64$ & $>64$ & $>64$ & $>64$ & $>64$ & $>64$ & 4 \\
\hline
\end{tabular}

* Flavodoxins that appear described as essential in the DEG database [40]. Not being in the DEG database does not necessarily mean they are essential.

The other Gram-negative bacteria tested, which belong to the class gamma-proteobacteria, are generally non-susceptible to any of the compounds, including isogenic LPS mutants of $P$. aeruginosa, S. maltophilia and K. pneumoniae tested to address potential permeabilization issues of the compounds across the outer membrane of the parental wild-type strains. However, most Gram-negative bacteria of the Helicobacter genus (9 species tested) and the closely related C. jejuni species (they both belong to the class epsilon-proteobacteria and the order Campylobacterales) are inhibited, at least by compounds IV and rac-IV-j. Within this group, $H$. pylori is inhibited by all the compounds tested (lead compound IV was initially discovered as an $\mathrm{Hp}$-Fld inhibitor); the five remaining gastric species (H. felis, H. suis, $H$. heilmannii, $H$. ailurogastricus and $H$. bizzozeronii) are inhibited at least by compounds IV and rac-IV-j at concentrations $\leq 32 \mu \mathrm{g} / \mathrm{mL}$ (the other compounds have not been tested in these species); and two out of three enterohepatic species tested (H. hepaticus, H. muridarum and H. bilis) are inhibited by compounds IV and $\mathbf{r a c}-\mathbf{I V}-\mathbf{j}$, but not by the rest of the compounds.

\subsection{Probable Interaction of the Inhibitors at a Pocket near the FMN Binding Site}

Interaction between wild-type $H p$-Fld and compounds IV, IV-a, IV-b, IV-c, IV-d, racIV-j, rac-IV-k and rac-IV-1 was evaluated by ITC (Figure S3 and Table S1). These studies reveal only small differences in the binding affinities of the compounds to the protein target, as they all exhibit dissociation constants in the micromolar range and a 1:1 protein:ligand stoichiometry. As shown, the interaction between wild-type $\mathrm{Hp}$-Fld and IV-derivatives is 
entropically driven, and characterised by a moderate affinity. The small contribution of the enthalpy balance is, in some cases, positive and in some others negative, which gives rise to the different tendencies of the binding curves.

Despite considerable efforts, the crystallization of a complex between $\mathrm{Hp}$-Fld and any of the inhibitors has not been possible yet. Considering the lack of structural information on flavodoxin-inhibitor complexes, molecular docking assays were carried out to try to understand the structural basis of the interaction between the protein and the inhibitors. These studies proposed one main binding hotspot for the inhibitors, which was located at the long-loop characteristic of long-chain flavodoxins. In particular, the best binding poses for compounds IV, IV-a, IV-b, IV-c and IV-d showed interaction with residues V113, Q115, T116 and K133 of the protein (Figure 3A). On the other hand, Hp-Fld shows a characteristic pocket near the FMN binding site, where the binding of small compounds has been proposed, that could interfere either with electron transfer or with the interaction of flavodoxin with other protein partners [11]. The pocket arises from the unusual presence in $\mathrm{Hp}$-Fld of an alanine residue (A55) at the si face of the cofactor, where other flavodoxins commonly bear a bulky residue. Three residues, namely: N14 and D142 (close to each other and interacting with the FMN phosphate and its ribityl moiety) and especially A55 (right at the pocket edge) have been noticed that could affect the binding of inhibitors at the pocket (Figure 3B).

A
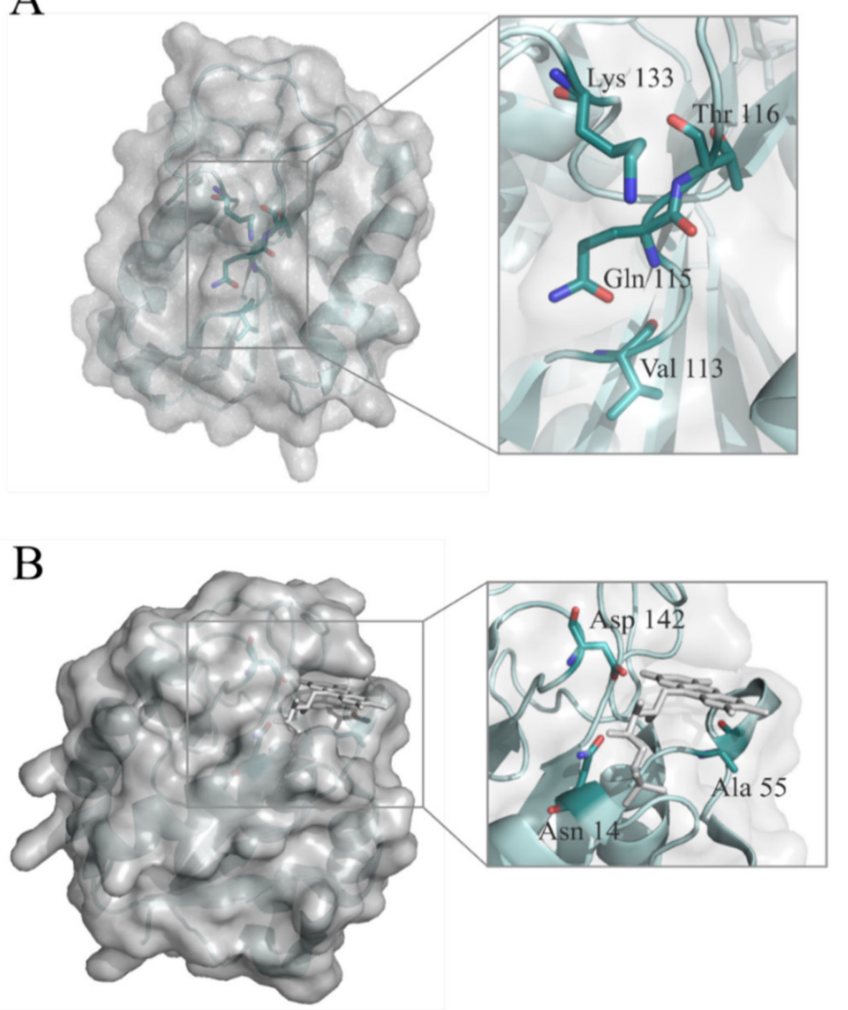

Figure 3. Molecular surface and ribbon models showing putative interacting residues of wild-type $H p$-Fld with compounds IV, IV-a, IV-b, IV-c and IV-d. (A): Val 113, Gln 115, Thr 116 and Lys 133, predicted by molecular docking, and (B): Asn 14, Ala 55 and Asp 142, close to the structural pocket near the cofactor binding site. The FMN cofactor is represented as grey sticks and the nitrogen and oxygen atoms from the amino acid residues are depicted as red and blue sticks, respectively.

In order to assess whether the protein region predicted by the docking analysis is the likely binding site for the inhibitors, residues V113, Q115 and T116 were mutated to tryptophan, which may introduce steric hindrance, and K133 was mutated to alanine, which removes the positive charge of the lysine side chain. At the alternative potential binding site located near the cofactor, N14 was replaced by an alanine in order to remove 
its hydrogen bonding groups, and A55 and D142 were replaced by bulkier tryptophan and tyrosine residues, respectively. The seven wild type residues replaced are located at the protein surface and the seven mutants $\mathrm{H} p$-Fld generated were expressed and purified with normal yields, and showed no indications of reduced conformational stability. The affinity of the complexes formed between wild-type or mutant $\mathrm{Hp}$-Fld with compounds IV and IV-c was determined by ITC (Figures 4 and S4).
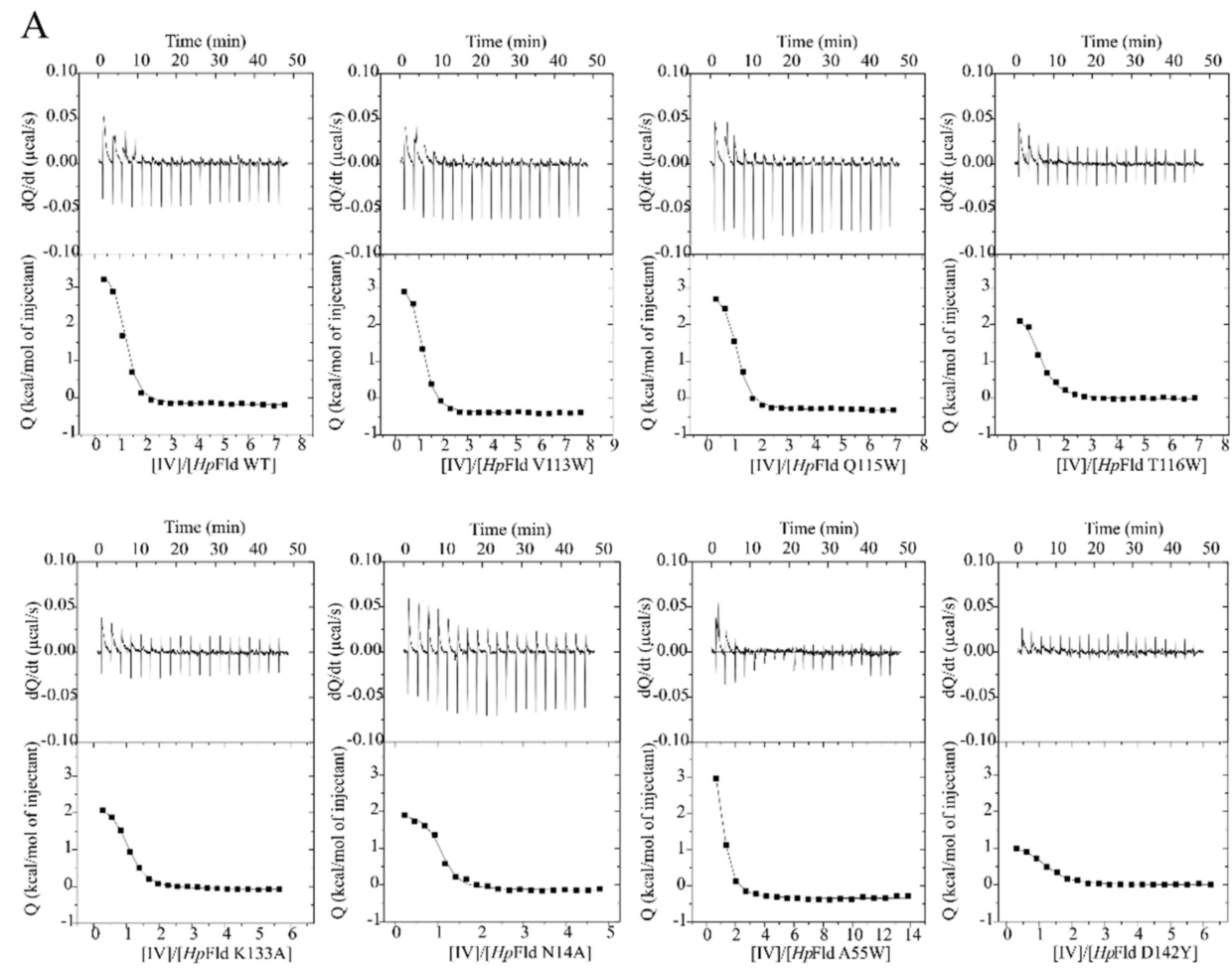

$\mathrm{B}$

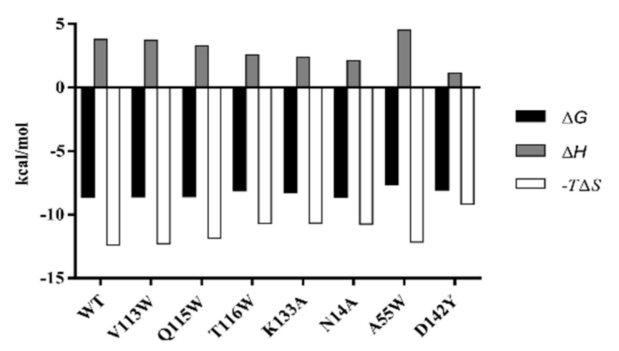

Figure 4. Thermodynamic analysis of the interaction between compound IV and wild-type Hp-Fld and mutants N14A, V113W, Q115W, T116W and K133A by ITC. (A) The upper plots show the thermograms (thermal power as a function of time), whereas the lower panels exhibit the binding isotherms (titrant normalised heat effects as a function of the ligand:protein molar ratio in the cell). In these last ones, the solid line corresponds to the best fit. (B) Thermodynamic parameters of each flavodoxin interaction with compound IV. Gibbs energy $(\Delta G)$, enthalpy $(\Delta H)$ and entropic contribution $(-T \Delta S)$ are represented in black, grey and white bars, respectively.

The thermodynamic profiles of the interactions between wild-type and mutant $\mathrm{Hp}$-Fld with either compound are similar. They indicate that all complexes are strongly stabilised by the binding entropy change and significantly destabilised by the enthalpy one (Table 2). The similarity of the thermodynamic profiles suggests that inhibitors IV and IV-c bind to all the mutant proteins at the same site as with the wild-type protein. Although no large changes in binding affinity occur in the mutants (Table 2), the data point to A55 as the amino acid residue whose replacement by a potentially interfering one cause the greatest changes in affinity. This is clearly seen in the complex between the protein and compound 
IV. In this complex, the replacement of A55 is the only one which decreases the affinity (as judged from the value of $\Delta G$ of binding) by more than $1 \mathrm{SD}$ from the mean value exhibited by the eight $H p$-Fld variants tested. Besides, the only substitution that makes the binding enthalpy of the complex even more unfavourable than in the wild-type protein is that of A55. The destabilization of the IV-c complex in the A55W mutant is not as large as in the IV complex, but its affinity is still below the mean of the IV-c complexes. Besides, if the affinity of each variant for IV and IV-c is averaged, the A55W mutant exhibits the weakest mean $(-7.89 \mathrm{kcal} / \mathrm{mol})$, being the only one below $1 \mathrm{SD}$ of the mean of all inhibitors' means $(-8.24 \pm 0.20 \mathrm{kcal} / \mathrm{mol})$. Altogether, the ITC binding study does not confirm the putative binding site predicted by the docking studies, but supports, although non-conclusively, the hypothesis that the inhibitors bind at the pocket near the Hp-Fld cofactor.

Table 2. Thermodynamic parameters of the complexes formed between wild-type and several mutant flavodoxins with compounds IV and IV-c a .

\begin{tabular}{|c|c|c|c|c|c|c|c|c|}
\hline \multirow{2}{*}{$\begin{array}{c}\text { Flavodoxin } \\
\text { Variant }\end{array}$} & \multicolumn{4}{|c|}{ IV } & \multicolumn{4}{|c|}{ IV-c } \\
\hline & $\begin{array}{l}K_{d} \mathbf{b} \\
(\mu \mathrm{M})\end{array}$ & $\begin{array}{c}\Delta G^{\mathrm{c}} \\
\text { (kcal/mol) }\end{array}$ & $\begin{array}{c}\Delta H^{\mathrm{d}} \\
\text { (kcal/mol) }\end{array}$ & $\begin{array}{c}-T \Delta S^{\mathrm{e}} \\
(\mathrm{kcal} / \mathrm{mol})\end{array}$ & $\begin{array}{l}K_{d} \mathrm{~b} \\
(\mu \mathrm{M})\end{array}$ & $\begin{array}{c}\Delta G^{\mathrm{c}} \\
(\mathrm{kcal} / \mathrm{mol})\end{array}$ & $\begin{array}{c}\Delta H^{\mathrm{d}} \\
\text { (kcal/mol) }\end{array}$ & $\begin{array}{c}-T \Delta S \mathrm{e} \\
(\mathrm{kcal} / \mathrm{mol})\end{array}$ \\
\hline WT & 0.48 & -8.58 & 3.77 & -12.35 & 0.67 & -8.39 & 3.10 & -11.49 \\
\hline V113W & 0.50 & -8.56 & 3.69 & -12.25 & 1.45 & -7.93 & 1.40 & -9.33 \\
\hline Q115W & 0.52 & -8.54 & 3.29 & -11.83 & 0.69 & -8.37 & 2.36 & -10.73 \\
\hline T116W & 1.10 & -8.10 & 2.58 & -10.68 & 1.43 & -7.94 & 1.68 & -9.62 \\
\hline K133A & 0.85 & -8.25 & 2.38 & -10.63 & 0.77 & -8.31 & 2.10 & -10.41 \\
\hline N14A & 0.45 & -8.62 & 2.10 & -10.72 & 1.76 & -7.82 & 2.61 & -10.43 \\
\hline A55W & 2.33 & -7.65 & 4.50 & -12.15 & 1.05 & -8.12 & 1.70 & -9.82 \\
\hline D142Y & 1.18 & $\begin{array}{c}-8.05 \\
-8.29 \pm 0.35 \\
\text { Mean } \pm \text { SD }\end{array}$ & 1.13 & -9.18 & 0.44 & $\begin{array}{c}-8.64 \\
-8.19 \pm 0.28 \\
\text { Mean } \pm \text { SD }\end{array}$ & 0.92 & -9.56 \\
\hline
\end{tabular}

a Obtained from calorimetric titrations in $50 \mathrm{mM}$ EPPS, $\mathrm{pH} 9 .{ }^{\mathrm{b}}$ Relative error in $K_{d}$ is $10 \% .{ }^{\mathrm{c}}$ Calculation of Gibbs energy change was based

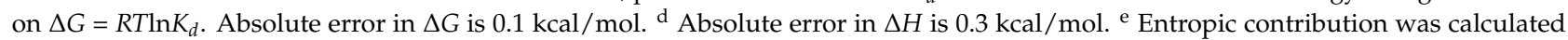
according to: $-T \Delta S=\Delta G-\Delta H$. Absolute error in $-T \Delta S$ is $0.3 \mathrm{kcal} / \mathrm{mol}$ [41].

These results are consistent with the fact that among the Helicobacter species (H. pylori, $H$. hepaticus, H. muridarum and H. bilis) plus C. jejuni, for which the whole battery of inhibitors has been tested (inhibitors IV to rac-IV-1), H. pylori is the only one bearing the alanine residue that generates the pocket near the cofactor (Figure 5), and the only one being inhibited by all the compounds tested (Table 1).

\subsection{Prospects of a Low H. pylori Resistance Rate to IV-Related Compounds}

Bacterial efflux pumps are membrane proteins able to actively transport a number of substances, including drugs, from the cytoplasm to the extracellular environment. Efflux reduces the antibacterial activity of some drugs by throwing them out from the cell, and is considered as a low-level antibiotic resistance mechanism that can favour and promote the development of higher levels of resistance. In order to determine whether IV-related compounds are affected by efflux systems, the MICs of these molecules were evaluated in combination with sub-inhibitory concentrations of three different efflux inhibitors (EIs): CCCP, reserpine and valinomycin. To do that, we first determined the MICs of these EIs against $H$. pylori reference strain ATCC 700392. Those MICs turned out to be of 0.32, 12.5 and $10 \mu \mathrm{g} / \mathrm{mL}$ for CCCP, reserpine and valinomycin, respectively. Each EI was added at a concentration of $\frac{1}{4} \mathrm{MIC}$, and it was considered that a compound could be significantly transported out by efflux pumps when its MIC was decreased by at least 4 times. As shown in Table 3, CCCP, reserpine and valinomycin were able to reduce the MIC of IV by a factor of 4, indicating that compound IV could be affected by efflux, although this effect would be just in the limit of what we consider as significant. In addition, reserpine and valinomycin lowered the MIC of IV-a by half, an effect which is also achieved by rac-IV-k when it was combined with valinomycin, suggesting that efflux could play a weak role (but not 
significant enough) in the activity of these compounds. On the other hand, the same MICs, or even moderately higher (two- to four-fold) MICs, were obtained for compounds IV-b, IV-c, IV-d and rac-IV-j, which indicates that the EIs tested would interfere moderately with the antimicrobial activity of $\mathrm{Hp}$-Fld inhibitors.

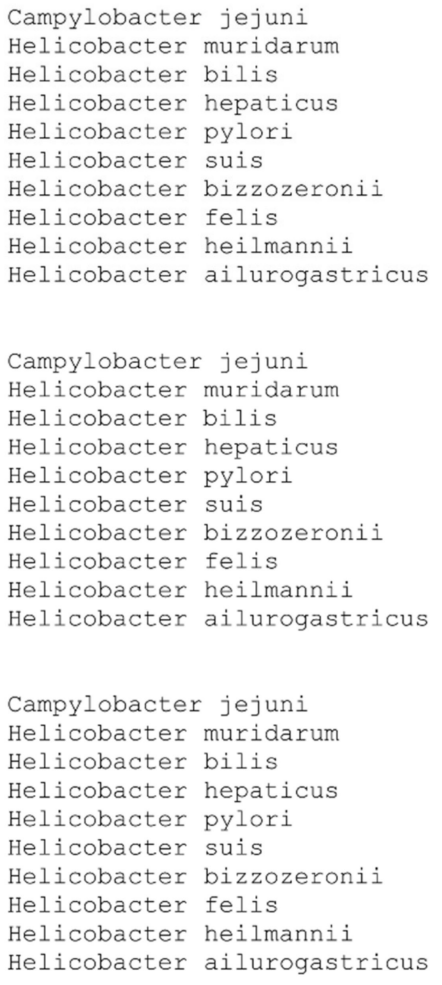

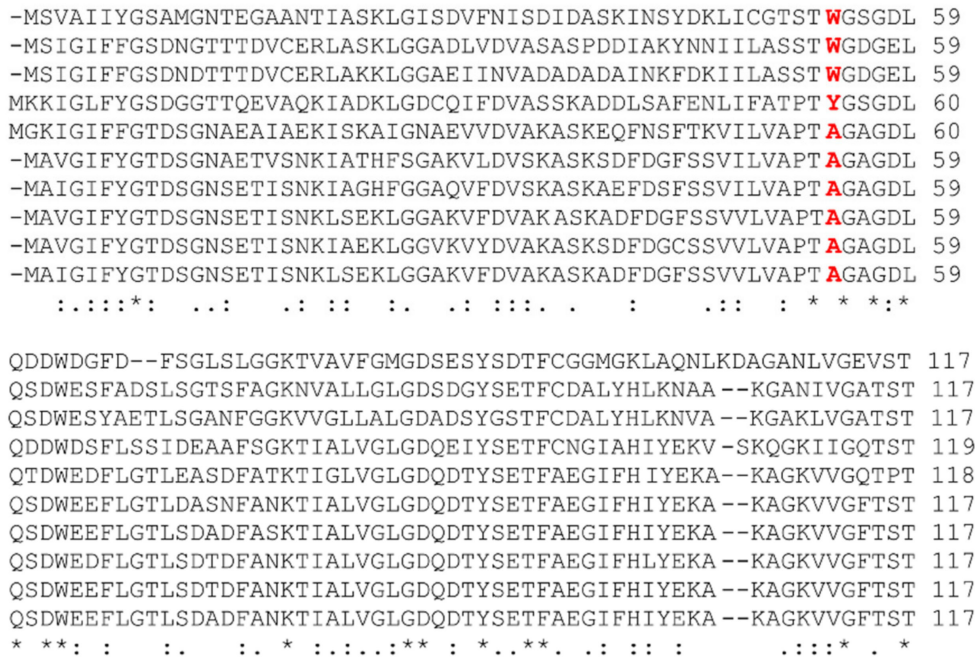

-MSVAI IYGSAMGNTEGAANTIASKLGISDVFNISDIDASKINSYDKLICGTST WGSGDL 59 -MSI GIFFGSDNGTTT DVCERLASKLGGADLVDVASASPDDIAKYNNI ILASST WGDGEL 59 -MSIGIFFGSDNDTTT DVCERLAKKLGGAEI INVADADADAINKFDKI ILASST WGDGEL 59 MKKIGLFYGSDGGTTQEVAOKIADKLGDCQIFDVASSKADDLSAFENLIFATPT YGSGDL 60 MGKIGIFFGTDSGNAEAIAEKISKAIGNAEVVDVAKASKEQFNSFTKVILVAPT AGAGDL 60 -MAVGIFYGTDSGNAETVSNKIATHFSGAKVLDVSKASKSDFDGFSSVILVAPT AGAGDL 59 -MAIGIFYGTDSGNSETISNKIAGHFGGAQVFDVSKASKAEFDSFSSVILVAPT AGAGDL 59 -MAVGIFYGTDSGNSETISNKLSEKLGGAKVFDVAKASKADFDGFSSVVLVAPTAGAGDL 59 -MAVGIFYGTDSGNSETISNKIAEKLGGVKVYDVAKASKSDFDGCSSVVLVAPT AGAGDL 59 -MAIGIFYGTDSGNSETISNKLSEKLGGAKVFDVAKASKADFDGFSSVVLVAPT AGAGDL 59

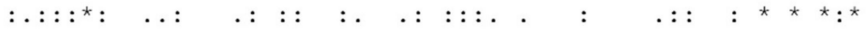

QDDWDGFD--FSGLSLGGKTVAVFGMGDSESYSDTFCGGMGKLAQNLKDAGANLVGEVST 117 QSDWESFADSLSGTSFAGKNVALLGLGDSDGYSETFCDALYHLKNAA --KGANIVGATST 117 QSDWESYAETLSGANFGGKVVGLLALGDADSYGSTFCDALYHLKNVA--KGAKLVGATST 117 QDDWDSFLSS I DEAAFSGKT IALVGLGDQE I YSETFCNG IAH I YEKV -SKQGKI IGQTST 119 QTDWEDFLGTLEASDFATKTIGLVGLGDQDTYSETFAEGIFH IYEKA--KAGKVVGQTPT 118 QSDWEEFLGTLDASNEANKT IALVGLGDQDTYSETFAEGIFHIYEKA--KAGKVVGFTST 117 QSDWEEFLGTLSDADFASKTIALVGLGDQDTYSETFAEGIFHIYEKA--KAGKVVGFTST 117 QSDWEDFLGTLSDTDFANKT IALVGLGDQDTYSETFAEGIFHLYEKA --KAGKVVGFTST 117 QSDWEEFLGTLSDTDFANKT IALVGLGDQDTYSETFAEGIFHIYEKA--KAGKVVGFTST 117 QSDWEEFLGTLSDADFANKTIALVGLGDQDTYSETFAEGIFHIYEKA--KAGKVVGFTST 117

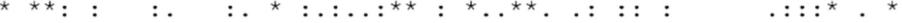

DGYTFEASDAVVDGKFVGLALDNDNQEDQTESRIDAWVEQIKPYFA 163 DGYEFDSSKGVENGKFVGLAIDEINQDDKTEERLDAWAKQLKSSGF 163 DGYEFDESKGVEGGKFVGLAIDEVNQDDKTDERLDAWVAQIKGEGF 163 DGYTFDESLAVVNGKFVGLVIDEVNOEDMTDSRIOAWVKTLKGAFA 165 DGYHFEASKAVEGGKFVGLVIDEDNQDDLTDERISKWVEQVKGSFA 164 DGYTFEGSKSVEGGKFVGLVLDVDNQDELTDGRISAWVNEIKGQLS 163 DGYNEEGSRSVENGKEVGLVLDEDNQDDLTDQRIEAWVKEVKGALS 163 DGYTFEASKSVODGKFVGLVLDEDNODDLTDERIOAWIOEIOGQLA 163 DGYNEEASRSVEGGKFVGLVLDEDNQDDLTDSRIDAWIGEVKGQLS 163 DGYNFEASRSVEGGKFVGLVLDEDNQDDLTDSRIDTWIGEVKGQLS 163

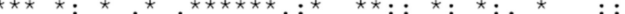

Figure 5. Multiple sequence alignment of flavodoxins from C. jejuni, H. muridarum, H. bilis, H. hepaticus, H. pylori, H. suis, H. bizzozeronii, H. felis, H. heilmannii and H. ailurogastricus. The alignment has been performed with Clustal Omega. [42] In all sequences, the amino acid residue at position 55 (according to $\mathrm{Hp}$-Fld numeration) is highlighted in red. As seen, the flavodoxins from H. pylori, H. suis, H. bizzozeronii, H. felis, H. heilmannii and H. ailurogastricus exhibit an alanine at this position, whereas a tyrosine is shown in that from $H$. hepaticus and a tryptophan is exhibited by those from $C$. jejuni, $H$. muridarum and H. bilis. Asterisks $\left(^{*}\right)$ highlight positions with a fully conserved residue; colons (:) indicate positions of residues with high similarity; dots (.) indicate positions with residues possessing weak similarity.

Table 3. In vitro activity of IV-related compounds alone and in combination with CCCP, reserpine and valinomycin against $H$. pylori strain ATCC 700392.

\begin{tabular}{|c|c|c|c|c|}
\hline \multirow[t]{2}{*}{ Compound } & \multicolumn{4}{|c|}{$\begin{array}{c}\mathrm{MIC}^{\mathrm{a}} \\
(\mu \mathrm{g} / \mathrm{mL})\end{array}$} \\
\hline & Without any EI & СССР & Reserpine & Valinomycin \\
\hline IV & 2 & 0.5 & 0.5 & 0.5 \\
\hline IV-a & 8 & 8 & 4 & 4 \\
\hline IV-b & 1 & 2 & 2 & 2 \\
\hline IV-c & 2 & 4 & 4 & 4 \\
\hline IV-d & 8 & 32 & 32 & 32 \\
\hline$r a c-I V-j$ & 1 & 4 & 2 & 2 \\
\hline$r a c-\mathrm{IV}-\mathrm{k}$ & 16 & 16 & 16 & 8 \\
\hline rac-IV-1 & $>64$ & $>64$ & $>64$ & $>64$ \\
\hline Mnz & 2 & 4 & 4 & 2 \\
\hline Cla & $\leq 0.032$ & $\leq 0.032$ & $\leq 0.032$ & $\leq 0.032$ \\
\hline
\end{tabular}

a The MIC values were assayed in the presence of non-lethal concentrations of the following EPIs: CCCP $(0.08 \mu \mathrm{g} / \mathrm{mL})$, reserpine $(3.12 \mu \mathrm{g} / \mathrm{mL})$ and valinomycin $(2.50 \mu \mathrm{g} / \mathrm{mL})$. 
Altogether, these data showed that the antibacterial activity of IV-related compounds was not altered significantly by EIs, suggesting that the efflux pumps inhibited by those EIs were not able to actively transport any of the compounds of this family to a significant extent. Therefore, the intrinsic resistance of $H$. pylori to therapies based on these flavodoxin inhibitors can be regarded as moderate-low, which would make the development of higher resistance levels less likely.

In support of the latter observation, we were not able to select spontaneous mutants showing resistance to flavodoxin inhibitors. After incubating $H$. pylori strain ATCC 700,392 (at $5 \times 10^{6}$ and $5 \times 10^{7} \mathrm{CFU} / \mathrm{mL}$ ) in the presence of different concentrations $(0.5,1,2$, 4, 8, 16 and 32 times their MICs) of compounds IV, IV-d, rac-IV-1 and Mnz (as a control drug), the generation of spontaneous mutants was checked by MIC testing against those cultures. Whereas no significant changes in the MICs of compounds IV, IV-d and rac-IV-1 were observed against any of those cultures previously treated with the same compounds compared to the MIC for the wild-type strain, a 16-fold increase in Mnz MIC was recorded against a H. pylori culture previously exposed to a 4-fold MIC concentration of this drug, which indicates that Mnz-resistant mutants have been generated. Accordingly, the ability of $H$. pylori to develop resistance to those IV-related compounds seems to be much less pronounced than that to develop resistance against Mnz.

\subsection{Synergistic Interaction between Some IV-Related Compounds and Rabeprazole}

The bactericidal effect of compound IV and several derivatives in combination with anti-H. pylori drugs such as Mnz, Cla, omeprazole and rabeprazole was analysed in vitro, as well as that of compound IV combined with some of its derivatives. The synergistic effect was estimated by calculating the fractional inhibitory concentration index (FICI) for each pair of molecules. As the checkerboard assay requires previous knowledge of the MIC of the individual compounds, the MICs of omeprazole and rabeprazole against $H$. pylori strain ATCC 700,392 were also determined. Notably, the in vitro activity of rabeprazole $(\mathrm{MIC}=0.5 \mu \mathrm{g} / \mathrm{mL}$ ) was 64 times higher than that of omeprazole $(\mathrm{MIC}=32 \mu \mathrm{g} / \mathrm{mL})$. As seen in Table 4, whereas most compounds did not interact with IV, Mnz, Cla, omeprazole or rabeprazole (FICI > 0.5), compounds IV-b and rac-IV-1 showed a synergistic relation $(\mathrm{FICI}=0.5)$ with rabeprazole, indicating that the combined effect of these substances is significantly higher than the sum of their individual antimicrobial activities. Synergism was confirmed by plotting the FIC values of IV-b and rac-IV-l against the corresponding FIC values of rabeprazole as in both cases a concave curve was obtained (Figure 6). For those compounds, the most effective combinations for inhibiting $H$. pylori growth were $0.25 \mu \mathrm{g} / \mathrm{mL}$ of IV-b or $64 \mu \mathrm{g} / \mathrm{mL}$ of $\mathrm{rac}-\mathrm{IV}-\mathbf{1}$ plus $0.125 \mu \mathrm{g} / \mathrm{mL}$ of rabeprazole. Although significant synergism, as per our quantitative definition, was only found between the indicated pairs of substances, there were several compounds that clearly reduced the MICs of others. In particular, IV-a lowered the MIC of IV 64-fold (FIC = 0. 016; Table 4), whereas IV lowered that of Mnz 16-fold (FIC = 0.063). Notably, the combination of Cla with compounds IV-d, rac-IV-j or rac-IV-1 reduced their MICs 8-fold (FIC $=0.125$ ), an effect which was also observed for the omeprazole MIC when it was combined with IV$\mathbf{b}(\mathrm{FIC}=0.125)$. On the other hand, the combination of rabeprazole with IV-a or IV-d lowered their MICs 16- and 8-fold (FIC $=0.0625$ or 0.125 , respectively). Thus, in conclusion, these compounds improved the in vitro anti- $H$. pylori activity of those other molecules and, remarkably, IV and IV-b increased, respectively, the antimicrobial effect of $\mathbf{M n z}$ and omeprazole, two conventional drugs used to treat H. pylori infections. 
Table 4. FICs and FICIs of IV-related compounds in combination with either IV, Mnz, Cla, omeprazole or rabeprazole ${ }^{\mathrm{a}}$.

\begin{tabular}{|c|c|c|c|c|}
\hline $\begin{array}{l}\text { Combination } \\
\text { Compound }\end{array}$ & $\begin{array}{l}\text { IV-Related } \\
\text { Compound }\end{array}$ & FIC $_{\text {combination compound }}$ & FIC $_{\text {IV-related compound }}$ & FICI $^{b}$ \\
\hline \multirow{7}{*}{ IV } & IV-a & 0.016 & 0.5 & 0.516 \\
\hline & IV-b & 1 & 1 & 2 \\
\hline & IV-c & 1 & 1 & 2 \\
\hline & IV-d & 1 & 1 & 2 \\
\hline & $r a c-I V-j$ & 0.25 & 0.5 & 0.75 \\
\hline & $r a c-I V-k$ & 1 & 1 & 2 \\
\hline & rac-IV-1 & 0.25 & 0.5 & 0.75 \\
\hline \multirow{8}{*}{ Mnz } & IV & 0.063 & 0.5 & 0.56 \\
\hline & IV-a & 0.5 & 0.25 & 0.75 \\
\hline & IV-b & 0.5 & 0.5 & 1 \\
\hline & IV-c & 0.5 & 0.5 & 1 \\
\hline & IV-d & 0.5 & 0.5 & 1 \\
\hline & $r a c-I V-j$ & 0.5 & 0.5 & 1 \\
\hline & $r a c-I V-\mathbf{k}$ & 0.5 & 0.5 & 1 \\
\hline & rac-IV-1 & 0.5 & 0.5 & 1 \\
\hline \multirow{8}{*}{ Cla } & IV & 0.5 & 0.5 & 1 \\
\hline & IV-a & 0.5 & 0.25 & 0.75 \\
\hline & IV-b & 0.5 & 0.5 & 1 \\
\hline & IV-c & 0.5 & 0.25 & 0.75 \\
\hline & IV-d & 0.5 & 0.125 & 0.62 \\
\hline & $r a c-I V-j$ & 0.5 & 0.125 & 0.62 \\
\hline & $r a c-I V-k$ & 0.25 & 0.5 & 0.75 \\
\hline & rac-IV-1 & 0.5 & 0.125 & 0.62 \\
\hline \multirow{7}{*}{ Omeprazole } & IV & 0.5 & 0.5 & 1 \\
\hline & IV-a & 0.25 & 0.5 & 0.75 \\
\hline & IV-b & 0.125 & 0.5 & 0.62 \\
\hline & IV-d & 0.25 & 0.5 & 0.75 \\
\hline & $r a c-\mathbf{I V}-\mathbf{j}$ & 0.5 & 0.5 & 1 \\
\hline & $r a c-I V-k$ & 0.25 & 0.5 & 0.75 \\
\hline & rac-IV-1 & 0.5 & 0.5 & 1 \\
\hline \multirow{7}{*}{ Rabeprazole } & IV & 1 & 1 & 2 \\
\hline & IV-a & 0.5 & 0.063 & 0.56 \\
\hline & IV-b & 0.25 & 0.25 & 0.5 \\
\hline & IV-d & 0.5 & 0.125 & 0.62 \\
\hline & $r a c-\mathbf{I V}-\mathbf{j}$ & 0.5 & 0.5 & 1 \\
\hline & $r a c-I V-k$ & 0.5 & 0.5 & 1 \\
\hline & $r a c-I V-1$ & 0.25 & 0.25 & 0.5 \\
\hline
\end{tabular}

a Values were determined against H. pylori ATCC 700392. ${ }^{\mathrm{b}}$ The fractional inhibitory index (FICI) was cal-

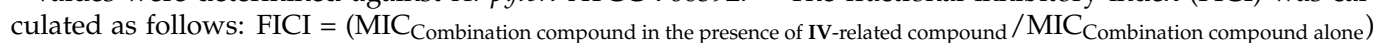

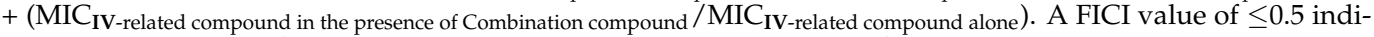
cates synergy, a value from 0.5 to 4 denotes no interaction and a value of $>4$ expresses antagonism. 


\section{A) Compound IV-b}

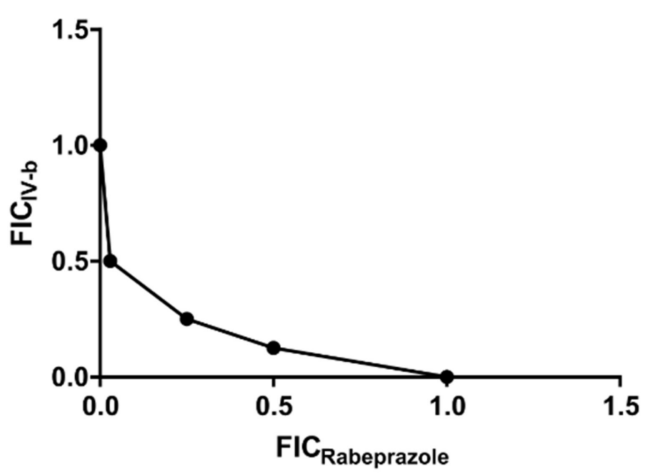

B) Compound rac-IV-I

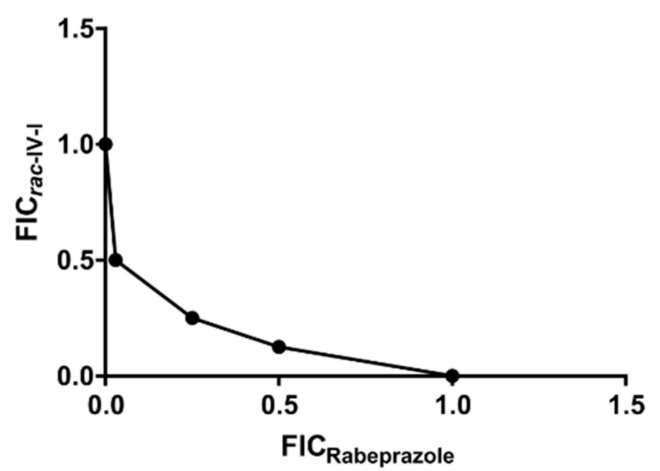

Figure 6. Synergism between rabeprazole and compounds IV-b (A) and rac-IV-1 (B) against H. pylori strain ATCC 700392. The concave curve obtained in both graphs by representing FIC values indicates a synergistic relation between rabeprazole and those IV-related compounds. The closest point to the axes intersection relates to the most effective combination of compounds to inhibit $H$. pylori growth, which is recorded as FICI.

\section{Discussion}

The emergence of resistant bacteria worldwide is a global health concern, of which the management requires coordinated efforts [43]. In particular, H. pylori resistance to currently used broad-spectrum antimicrobials has led to a decrease in the eradication rates, which brought about the inclusion of $\mathrm{H}$. pylori in the first-ever list of antibiotic-resistant priority pathogens published by the WHO in 2017 [7]. In order to address this problem, new selective treatments have been proposed, one of them being the development of new compounds acting on specific bacterial targets such as flavodoxin [10]. This is an essential protein for H. pylori and it is absent in humans, which makes it a promising pharmacological target [11]. In earlier work, three flavodoxin inhibitors (I, II and IV) were discovered [16] and derivatised [17] to improve their therapeutic indexes against H. pylori. In the second round of optimization, the modification of nitro and sulphide groups present in one of the original leads (compound IV) increased its therapeutic activity against some reference strains and several drug-resistant clinical isolates. Moreover, this family of compounds was also able to decrease $H$. pylori gastric colonization rates in a mice model of infection and to eradicate it in up to $60 \%$ of mice treated [18]. The goal of the present study was to develop a better understanding of the antimicrobial spectrum and the mechanism of action of this family of antimicrobials. The compounds have been tested against $8 \mathrm{Gram}$-positive and $15 \mathrm{Gram}$-negative bacteria. The Gram-negative bacteria tested comprise 7 genera of the phylum Proteobacteria, of which the Helicobacter genus is represented by 3 enterohepatic species (H. hepaticus, H. muridarum and $H$. bilis) and 6 gastric species (H. pylori, H. felis, H. suis, $H$. heilmannii, $H$. ailurogastricus and H. bizzozeronii). Most IV-related compounds showed potent antimicrobial activity against $H$. pylori. However, the antimicrobial spectrum (Table 1) was not the same for all of them.

Compounds IV and rac-IV-j are extended-spectrum antimicrobials that are effective against the Gram-positive bacteria and Gram-negative bacteria of the Helicobacter genus (plus $C$. jejuni), but they are ineffective against any of the other Gram-negative bacteria tested, belonging to 5 different genera. As they are effective against potential pathogenic bacteria for humans [10], such as H. pylori, H. suis, H. felis, H. heilmannii, H. bizzozeronii, C. jejuni, some Bacillus species, S. pneumoniae, E. faecalis, S. aureus and C. diphtheriae, they could be used as co-adjuvants, or as an alternative treatment for the corresponding infections. This could be particularly useful for C. jejuni, S. pneumoniae and S. aureus, which were also included in the WHO priority list of antibiotic-resistant bacteria that represent a great threat to human health [7]. The additional compounds (IV-a, IV-b, IV-c, IV-d and rac-IV-k) are ineffective against Gram-positive and Gram-negative alike, except $H$. pylori, for which they 
all show a potent inhibitory activity ( $r a c-I V-1$, perhaps related to its much high hydrophilicity, was ineffective against all bacterial species tested). Within the Helicobacter genus, we have determined that none of them inhibits the growth of enterohepatic species (Table 1), but their activity against other gastric species remains to be tested. These compounds (IV-a, IV-b, IV-c, IV-d, rac-IV-k) are thus narrow-spectrum antibiotics effective against $H$. pylori and perhaps against other gastric species of the Helicobacter genus, but not even against the enterohepatic Helicobacter species tested or C. jejuni. Importantly, these compounds are not effective against bacteria that may be part of the human microbiota, such as E. faecalis, $S$. aureus, S. pneumoniae and E. coli [10] at concentrations as high as $64 \mu \mathrm{g} / \mathrm{mL}$. The narrow antimicrobial spectrum of these compounds may limit the side effects on microbiota of anti-H. pylori therapies based on or including them.

The mechanism of action of these antimicrobials is not fully understood. They were initially discovered as compounds that bind to and inhibit the in vitro activity of purified $H p$-flavodoxin. All related inhibitors so far tested (this work and [16-18]) have been shown to bind to the purified protein. In this respect, most flavodoxins embed the FMN redox cofactor by sandwiching its isoalloxazine redox-active ring between two bulky residues (typically a tryptophan at the $50^{\prime}$ loop and a tyrosine at the $90^{\prime}$ loop). In contrast, at the equivalent position of the $50^{\prime}$ loop, $\mathrm{Hp}$-Fld contains an alanine residue (A55), whose small size contributes to creating a distinct pocket at the si face of the cofactor. The flavodoxin inhibitors have been speculated to bind at that pocket [16]. As shown in Figure 5, this peculiar sequence feature is shared with the flavodoxins of gastric Helicobacter species, but is absent in those of enterohepatic species of this genus and in C. jejuni. Given the present lack of precise structural information about the inhibitors binding site, we have resourced to protein engineering to try to identify surface residues that may be at the binding site or nearby. Thus, we have mutated seven residues of the flavodoxin surface which are located either at a putative binding site identified through docking analysis (V113, Q115, T116 and K133A) or at the FMN binding site (A55 which is the residue that creates the pocket, and N14A and D142Y which interact with the phospho-ribityl moiety of the FMN cofactor). ITC analysis (Figures 4 and S4, and Table 2) of the affinity of wild-type and mutant flavodoxins for two representative inhibitors (IV and IV-c) suggests that the residues located at the putative binding site do not interact with the inhibitors or lay close to the interacting site, as their replacement does not perturb the binding. The same appears to be the case of residues 14 and 142, in contact with the phosphate and ribityl moieties of the FMN cofactor. In contrast, the replacement of A55 by tryptophan stands out as the only replacement that clearly lowers the inhibitors' affinity. The ITC analysis thus lends no support to the putative binding site suggested by the docking analysis, but is consistent with the A55 pocket being the likely binding site for the inhibitors, as previously proposed [16]. This observation will require further confirmation, as the A55W mutant weakens but does not abrogate the binding of the inhibitors.

Binding to the $H p$-Fld specific pocket near the cofactor remains a likely structural explanation for the antimicrobial activity of the flavodoxin inhibitors and explains why compounds IV-a, IV-b, IV-c, IV-d, rac-IV-k are antimicrobials for $H$. pylori, but not for the three enterohepatic Helicobacter species tested, which lack the pocket. However, it does not explain why two inhibitors, IV and rac-IV-j, are effective not only for $H$. pylori but also for two enterohepatic Helicobacter species (H. muridarum and H. bilis), for C. jejuni and, even more remarkably, for most Gram-positive bacteria tested. These two compounds, IV and rac-IV-j, unlike the other analogues, are the only nitro-derivatives of the tested series and it is possible that the nitro functionality allows them to act by an additional mechanism, which could explain their extended antimicrobial spectrum. As compounds IV and rac-IV-j are more cytotoxic towards HeLa cells [18] than the other compounds of this family, they might be targeting additional proteins or, once in the bacterial cells, they could be transformed into cytotoxic compounds, as has been described for Mnz, which also contains a nitro group. The greater permeability of monoderm Gram-positive bacteria compared to diderm Gram-negative ones might contribute to compounds IV and rac-IV-j 
reaching higher concentrations in the cytoplasm of these Gram-positive bacteria, where they could exert their alternative antimicrobial activity, unlike in Gram-negative bacteria. Whatever the case, it seems that replacing the nitro group in IV and rac-IV-j by its reduced amine version greatly increases the selectivity of this family of compounds, and turns them from extended-spectrum to narrow-spectrum antimicrobials highly specific to H. pylori and perhaps for other gastric Helicobacter species.

No spontaneous mutants were obtained when $H$. pylori cultures were incubated in the presence of high concentrations of some IV-related compounds under the same conditions, which allowed us to generate Mnz resistant mutants. As determined by Wang et al., Mnz showed an in vitro mutation rate of $6.9 \times 10^{-10}$ per cell per division, which was less than those of Cla, ciprofloxacin, and rifampicin [44]. Given that all these antimicrobials are included in H. pylori eradication therapies [45-50], replacing some of them with IV-related compounds could help to reduce the development of drug resistance in this bacterium. On the other hand, the more severe antibiotic resistance associated with Gram-negative bacteria compared to Gram-positive ones appears to be related to several drug resistance mechanisms, including the overexpression of efflux pumps in the former [51-53]. Indeed, $H$. pylori multidrug-resistance is associated with the activation of efflux pumps [54,55]. Thus, compounds inhibiting efflux pumps are expected to influence internal concentrations of substances such as antibiotics, and combined use of EIs with antimicrobials might increase bacterial susceptibility [51,55-57]. CCCP, reserpine or valinomycin inhibit ABC, DMT, MATE, MFS and/or RND [51,55,58-65], which are the main conserved families of bacterial efflux pumps [51,65-67]. As the antimicrobial activity of compound IV derivatives is not greatly affected by those EIs, these IV-related antimicrobials do not seem to be substrates of the most common types of bacterial efflux pumps, which adds to their potential to bypass intrinsic resistance mechanisms of $H$. pylori.

The use of antimicrobial monotherapies might boost the selection of drug-resistant strains, so combinations of drugs could be useful to reduce the selection of antibiotic resistance $[37,38,68]$. In this regard, the interaction between IV-related compounds and other pharmacological entities in use against $H$. pylori has been evaluated by the checkerboard assay [69]. Most of the derivatives tested did not exhibit synergy when combined with lead compound IV, Mnz, Cla, omeprazole or rabeprazole. However, compounds IV-b and rac-IV-1 showed synergy with rabeprazole. While both omeprazole and rabeprazol inhibit urease activity in vitro, rabeprazol does it at a lower concentration [70,71], which agrees with our determined MICs for either PPI. Rabeprazole effect on gastric acid secretion seems to be more potent and fast than that of omeprazole [71] and it appears to be less affected by CYP2C19 polymorphisms [45]. These facts, together with the synergy observed, makes rabeprazole the PPI of choice in a treatment based on IV-related compounds. Since two compounds that show a synergistic relationship are not expected to act on the same target or, at least, on the same region of the target, the human gastric proton pump $\left(\mathrm{H}^{+} / \mathrm{K}^{+}\right.$-ATPase $)$and $H$. pylori urease might be discarded as targets of compounds IV-b and rac-IV-1 [71]. Importantly, even if synergism was not reached, compounds IV and IV-b decreased 8- and 16-fold, respectively, the MICs of omeprazole and Mnz against H. pylori, which could enhance their activities in a combinatory therapy, and supports the potential of compounds IV and IV-b as adjuvants in current combinatory therapies containing $\mathbf{M n z}$ or omeprazole.

\section{Conclusions}

Compound IV and related inhibitors of the flavodoxin from Helicobacter pylori are effective antimicrobials against different bacteria. Those bearing an amine functionality are narrow-spectrum antimicrobials highly specific against $H$. pylori and, possibly, other gastric, but not enterohepatic, Helicobacter species. The two compounds tested that contain a nitro functionality show an extended-spectrum activity against Gram-positive bacteria, the Helicobacter genus and C. jejuni. The extended spectrum antimicrobials may find use in novel therapies against Gram-positive bacteria, while the narrow-spectrum ones may 
be useful against $H$. pylori. Interestingly, these narrow spectrum antimicrobials are not substrates of common efflux pumps, appear to have a lower resistance rate than Mnz, show synergy with rabeprazole and may contribute to lowering the development of drug resistance in H. pylori. Besides, they might help to reduce the damage to the microbiota if included in eradication therapies, replacing some of the currently used antimicrobials.

Supplementary Materials: The following are available online at https://www.mdpi.com/article/10 $.3390 / \mathrm{ijms} 221810137 / \mathrm{s} 1$.

Author Contributions: Conceptualization, J.S.; methodology, S.S., J.J.G.-F., A.M., R.M., M.C.-G., E.A.C., H.B., A.V.-C., E.T., U.M., U.E.S., J.A.G., M.D.D.-d.-V., F.H., J.A.A., J.S.; formal analysis, S.S., A.M., R.M., H.B., A.V.-C., U.M., J.A.A., J.S.; resources, E.T., U.M., U.E.S., J.A.G., M.D.D.-d.-V., F.H., J.A.A., J.S.; writing —original draft preparation, S.S., J.S.; writing—review and editing, S.S., J.J.G.-F., A.M., R.M., M.C.-G., H.B., A.V.-C., E.T., U.M., U.E.S., J.A.G., M.D.D.-d.-V., F.H., J.A.A., J.S.; supervision, J.A.A., J.S.; funding acquisition, J.S. All authors have read and agreed to the published version of the manuscript.

Funding: We acknowledge financial support from JPIAMR (FLAV4AMR grant); INTERREG POCTEFA aCCeSS, EU (grant Infecmol); MINECO, Spain, (PID2019-107293GB-I00 grant); Gobierno de Aragón, Spain (E45_20R and LMP30_18 grants); and Maria Sklodowska-Curie grant agreement No 801586.

Institutional Review Board Statement: Not applicable.

Informed Consent Statement: Not applicable.

Data Availability Statement: The data to this study can be shared upon reasonable request from the corresponding author.

Acknowledgments: We acknowledge Pilar Mañas from the University of Zaragoza (Spain) and Mirko Rossi from the University of Helsinki (Finland) for donating some C. jejuni and H. bizzozeronii strains, respectively. We would like to thank Manuel Hein and Dörte Grella (Research Center Borstel) for their excellent technical assistance.

Conflicts of Interest: The authors declare no conflict of interest.

\section{References}

1. De Brito, B.B.; Da Silva, F.A.F.; Soares, A.S.; Pereira, V.A.; Santos, M.L.C.; Sampaio, M.M.; Neves, P.H.M.; De Melo, F.F. Pathogenesis and clinical management of Helicobacter pylori gastric infection. World J. Gastroenterol. 2019, 25, 5578-5589. [CrossRef] [PubMed]

2. Percival, S.; Williams, D.W. Chapter 7-Helicobacter pylori. In Microbiology of Waterborne Diseases; Academic Press: New York, NY, USA, 2014; pp. 119-154.

3. Zhang, X.-Y.; Zhang, P.-Y.; Aboul-Soud, M.A. From inflammation to gastric cancer: Role of Helicobacter pylori. Oncol. Lett. 2016, 13, 543-548. [CrossRef] [PubMed]

4. $\quad$ Backert, S.; Neddermann, M.; Maubach, G.; Naumann, M. Pathogenesis of Helicobacter pylori infection. Helicobacter 2016, $21,19-25$. [CrossRef] [PubMed]

5. WHO-IARC. Agents Classified by the IARC Monographs, Volumes 1-129. 2021. Available online: https://monographs.iarc. who.int/list-of-classifications (accessed on 11 July 2021).

6. O'Connor, A.; Furuta, T.; Gisbert, J.P.; O'Morain, C. Review-Treatment of Helicobacter pylori infection 2020. Helicobacter 2020, 25, e12743. [CrossRef] [PubMed]

7. Tacconelli, E.; Carrara, E.; Savoldi, A.; Harbarth, S.; Mendelson, M.; Monnet, D.L.; Pulcini, C.; Kahlmeter, G.; Kluytmans, J.; Carmeli, Y.; et al. Discovery, research, and development of new antibiotics: The WHO priority list of antibiotic-resistant bacteria and tuberculosis. Lancet Infect. Dis. 2018, 18, 318-327. [CrossRef]

8. Liou, J.; Lee, Y.; Wu, M. Treatment of Helicobacter pylori infection and its long-term impacts on gut microbiota. J. Gastroenterol. Hepatol. 2020, 35, 1107-1116. [CrossRef]

9. Ghobadi, E.; Ghanbarimasir, Z.; Emami, S. A review on the structures and biological activities of anti-Helicobacter pylori agents. Eur. J. Med. Chem. 2021, 223, 113669. [CrossRef] [PubMed]

10. Salillas, S.; Sancho, J. Flavodoxins as Novel Therapeutic Targets against Helicobacter pylori and Other Gastric Pathogens. Int. J. Mol. Sci. 2020, 21, 1881. [CrossRef] [PubMed]

11. Cremades, N.; Bueno, M.; Toja, M.; Sancho, J. Towards a new therapeutic target: Helicobacter pylori flavodoxin. Biophys. Chem. 2005, 115, 267-276. [CrossRef] [PubMed]

12. Freigang, J.; Diederichs, K.; Schäfer, K.P.; Welte, W.; Paul, R. Crystal structure of oxidized flavodoxin, an essential protein in Helicobacter pylori. Protein Sci. 2009, 11, 253-261. [CrossRef] [PubMed] 
13. Cremades, N.; Velazquez-Campoy, A.; Freire, E.; Sancho, J. The Flavodoxin from Helicobacter pylori: Structural Determinants of Thermostability and FMN Cofactor Binding. Biochemistry 2007, 47, 627-639. [CrossRef]

14. Maurice, M.S.; Cremades, N.; Croxen, M.; Sisson, G.; Sancho, J.; Hoffman, P.S. Flavodoxin:Quinone Reductase (FqrB): A Redox Partner of Pyruvate:Ferredoxin Oxidoreductase That Reversibly Couples Pyruvate Oxidation to NADPH Production in Helicobacter pylori and Campylobacter jejuni. J. Bacteriol. 2007, 189, 4764-4773. [CrossRef]

15. López-Llano, J.; Maldonado, S.; Bueno, M.; Lostao, A.; Jimenez, M.A.; Lillo, M.P.; Sancho, J. The Long and Short Flavodoxins: I. The role of the differentiating loop in apoflavodoxin structure and FMN binding. J. Biol. Chem. 2004, 279, 47177-47183. [CrossRef] [PubMed]

16. Cremades, N.; Velázquez-Campoy, A.; Martínez-Júlvez, M.; Neira, J.L.; Pérez-Dorado, I.; Hermoso, J.; Jiménez, P.; Lanas, A.; Hoffman, P.S.; Sancho, J. Discovery of Specific Flavodoxin Inhibitors as Potential Therapeutic Agents against Helicobacter pylori Infection. ACS Chem. Biol. 2009, 4, 928-938. [CrossRef] [PubMed]

17. Galano, J.J.; Alías, M.; Pérez, R.; Velázquez-Campoy, A.; Hoffman, P.S.; Sancho, J. Improved Flavodoxin Inhibitors with Potential Therapeutic Effects against Helicobacter pylori Infection. J. Med. Chem. 2013, 56, 6248-6258. [CrossRef]

18. Salillas, S.; Alías, M.; Michel, V.; Mahía, A.; Lucía, A.; Rodrigues, L.; Bueno, J.; Galano-Frutos, J.J.; De Reuse, H.; VelázquezCampoy, A.; et al. Design, Synthesis, and Efficacy Testing of Nitroethylene- and 7-Nitrobenzoxadiazol-Based Flavodoxin Inhibitors against Helicobacter pylori Drug-Resistant Clinical Strains and in Helicobacter pylori-Infected Mice. J. Med. Chem. 2019, 62, 6102-6115. [CrossRef] [PubMed]

19. Flahou, B.; Haesebrouck, F.; Smet, A.; Yonezawa, H.; Osaki, T.; Kamiya, S. Gastric and Enterohepatic Non-Helicobacter pylori Helicobacters. Helicobacter 2013, 18, 66-72. [CrossRef] [PubMed]

20. Ménard, A.; Smet, A. Review: Other Helicobacter species. Helicobacter 2019, 24, e12645. [CrossRef] [PubMed]

21. Smet, A.; Yahara, K.; Rossi, M.; Tay, A.; Backert, S.; Armin, E.; Fox, J.G.; Flahou, B.; Ducatelle, R.; Haesebrouck, F.; et al. Macroevolution of gastric Helicobacter species unveils interspecies admixture and time of divergence. ISME J. 2018, 12, $2518-2531$. [CrossRef] [PubMed]

22. Rahim, R.; Burrows, L.L.; Monteiro, M.A.; Perry, M.B.; Lam, J.S. Involvement of the rml locus in core oligosaccharide and O polysaccharide assembly in Pseudomonas aeruginosa. Microbiology 2000, 146, 2803-2814. [CrossRef]

23. Jacobs, M.A.; Alwood, A.; Thaipisuttikul, I.; Spencer, D.; Haugen, E.; Ernst, S.; Will, O.; Kaul, R.; Raymond, C.; Levy, R.; et al. Comprehensive transposon mutant library of Pseudomonas aeruginosa. Proc. Natl. Acad. Sci. USA 2003, 100, 14339-14344. [CrossRef]

24. Held, K.; Ramage, E.; Jacobs, M.; Gallagher, L.; Manoil, C. Sequence-Verified Two-Allele Transposon Mutant Library for Pseudomonas aeruginosa PAO1. J. Bacteriol. 2012, 194, 6387-6389. [CrossRef] [PubMed]

25. McCallum, K.L.; Schoenhals, G.; Laakso, D.; Clarke, B.; Whitfield, C. A high-molecular-weight fraction of smooth lipopolysaccharide in Klebsiella serotype O1:K20 contains a unique O-antigen epitope and determines resistance to nonspecific serum killing. Infect. Immun. 1989, 57, 3816-3822. [CrossRef] [PubMed]

26. Whitfield, C.; Richards, J.C.; Perry, M.B.; Clarke, B.R.; MacLean, L.L. Expression of two structurally distinct D-galactan O antigens in the lipopolysaccharide of Klebsiella pneumoniae serotype O1. J. Bacteriol. 1991, 173, 1420-1431. [CrossRef]

27. Clarke, B.R.; Whitfield, C. Molecular cloning of the $\mathrm{rfb}$ region of Klebsiella pneumoniae serotype O1:K20: The rfb gene cluster is responsible for synthesis of the D-galactan I O polysaccharide. J. Bacteriol. 1992, 174, 4614-4621. [CrossRef]

28. Avison, M.B.; Von Heldreich, C.J.; Higgins, C.S.; Bennett, P.M.; Walsh, T.R. A TEM-2 beta-lactamase encoded on an active Tn1-like transposon in the genome of a clinical isolate of Stenotrophomonas maltophilia. J. Antimicrob. Chemother. 2000, 46, 879-884. [CrossRef] [PubMed]

29. Steinmann, J.; Mamat, U.; Abda, E.M.; Kirchhoff, L.; Streit, W.; Schaible, U.E.; Niemann, S.; Kohl, T.A. Analysis of Phylogenetic Variation of Stenotrophomonas maltophilia Reveals Human-Specific Branches. Front. Microbiol. 2018, 9. [CrossRef] [PubMed]

30. Van den Bulck, K.; Decostere, A.; Gruntar, I.; Baele, M.; Krt, B.; Ducatelle, R.; Haesebrouck, F. In Vitro Antimicrobial Susceptibility Testing of Helicobacter felis, H. bizzozeronii, and H. salomonis. Antimicrob. Agents Chemother. 2005, 49, 2997-3000. [CrossRef]

31. Berlamont, H.; Smet, A.; De Bruyckere, S.; Boyen, F.; Ducatelle, R.; Haesebrouck, F.; De Witte, C. Antimicrobial susceptibility pattern of Helicobacter suis isolates from pigs and macaques. Vet. Microbiol. 2019, 239, 108459. [CrossRef]

32. Clinical and Laboratory Standards Institute (CLSI). Performance Standards for Antimicrobial Susceptibility Testing. M100-ED29, 29th ed.; Clinical and Laboratory Standards Institute: Wayne, PA, USA, 2019.

33. Campos, L.A.; Sancho, J. Native-specific stabilization of flavodoxin by the FMN cofactor: Structural and thermodynamical explanation. Proteins Struct. Funct. Bioinform. 2006, 63, 581-594. [CrossRef] [PubMed]

34. Frisch, M.J.; Trucks, G.W.; Schlegel, H.B.; Scuseria, G.E.; Robb, J.R.; Bloino, J.; Kudin, K.N.; Cossi, M.; Rega, N.; Pomelli, C.; et al. Gaussian 09, Revision D.01; Gaussian Inc.: Wallingford, CT, USA, 2013.

35. Morris, G.; Huey, R.; Lindstrom, W.; Sanner, M.F.; Belew, R.K.; Goodsell, D.S.; Olson, A.J. AutoDock4 and AutoDockTools4: Automated docking with selective receptor flexibility. J. Comput. Chem. 2009, 30, 2785-2791. [CrossRef] [PubMed]

36. Odds, F.C. Synergy, antagonism, and what the chequerboard puts between them. J. Antimicrob. Chemother. 2003, 52, 1. [CrossRef] [PubMed]

37. Ramón-García, S.; Martín, C.; Aínsa, J.A.; De Rossi, E. Characterization of tetracycline resistance mediated by the efflux pump Tap from Mycobacterium fortuitum. J. Antimicrob. Chemother. 2006, 57, 252-259. [CrossRef] 
38. Aguilar-Pérez, C.; Gracia, B.; Rodrigues, L.; Vitoria, A.; Cebrian, R.; Brodin, P.; Maqueda, M.; Ainsa, J.; Song, O.-R. Synergy between circular bacteriocin AS-48 and ethambutol against Mycobacterium tuberculosis. Antimicrob. Agents Chemother. 2018, 62, e00359-18. [CrossRef] [PubMed]

39. The European Committee on Antimicrobial Susceptibility Testing. Breakpoints Tables for Interpretation of MICs and Zones Diameters. Version 10.0. 2020. Available online: http:/ / www.eucast.org (accessed on 8 September 2021).

40. Luo, H.; Lin, Y.; Gao, F.; Zhang, C.-T.; Zhang, R. DEG 10, an update of the database of essential genes that includes both protein-coding genes and noncoding genomic elements: Table 1. Nucleic Acids Res. 2013, 42, D574-D580. [CrossRef]

41. Claveria-Gimeno, R.; Lanuza, P.M.; Morales-Chueca, I.; Torres, O.D.L.C.J.; Vega, S.; Abian, O.; Esteller, M.; Velazquez-Campoy, A. The intervening domain from MeCP2 enhances the DNA affinity of the methyl binding domain and provides an independent DNA interaction site. Sci. Rep. 2017, 7, srep41635. [CrossRef] [PubMed]

42. Madeira, F.; Park, Y.M.; Lee, J.; Buso, N.; Gur, T.; Madhusoodanan, N.; Basutkar, P.; Tivey, A.R.N.; Potter, S.C.; Finn, R.D.; et al. The EMBL-EBI search and sequence analysis tools APIs in 2019. Nucleic Acids Res. 2019, 47, W636-W641. [CrossRef]

43. Rossolini, G.M.; Arena, F.; Pecile, P.; Pollini, S. Update on the antibiotic resistance crisis. Curr. Opin. Pharmacol. 2014, 18, 56-60. [CrossRef] [PubMed]

44. Wang, G.; Wilson, T.J.M.; Jiang, Q.; Taylor, D.E. Spontaneous Mutations That Confer Antibiotic Resistance in Helicobacter pylori. Antimicrob. Agents Chemother. 2001, 45, 727-733. [CrossRef] [PubMed]

45. Malfertheiner, P.; Megraud, F.; O’Morain, C.; Gisbert, J.; Kuipers, E.; Axon, A.; Bazzoli, F.; Gasbarrini, A.; Atherton, J.; Graham, D.; et al. Management of Helicobacter pylori infection-the Maastricht V/Florence Consensus Report. Gut 2016, 66, 6-30. [CrossRef]

46. Fallone, C.A.; Chiba, N.; van Zanten, S.V.; Fischbach, L.; Gisbert, J.P.; Hunt, R.H.; Jones, N.L.; Render, C.; Leontiadis, G.I.; Moayyedi, P.; et al. The Toronto Consensus for the Treatment of Helicobacter pylori Infection in Adults. Gastroenterology 2016, 151, 51-69.e14. [CrossRef]

47. Flores-Treviño, S.; Mendoza-Olazarán, S.; Bocanegra-Ibarias, P.; Maldonado-Garza, H.J.; Garza-González, E. Helicobacter pylori drug resistance: Therapy changes and challenges. Expert Rev. Gastroenterol. Hepatol. 2018, 12, 819-827. [CrossRef] [PubMed]

48. Chey, W.D.; Leontiadis, G.I.; Howden, C.W.; Moss, S.F. ACG Clinical Guideline: Treatment of Helicobacter pylori Infection. Am. J. Gastroenterol. 2017, 112, 212-239. [CrossRef]

49. Gisbert, J.P.; Molina-Infante, J.; Amador, J.; Bermejo, F.; Bujanda, L.; Calvet, X.; Castro-Fernandez, M.; Cuadrado-Lavín, A.; Elizalde, J.I.; Gene, E.; et al. IV Spanish consensus conference on Helicobacter pylori infection treatment. Gastroenterol. Hepatol. 2016, 39, 697-721. [CrossRef] [PubMed]

50. Aboderin, O.A.; Abdu, A.R.; Odetoyin, B.; Okeke, I.N.; Lawal, O.; Ndububa, A.D.; Agbakwuru, E.A.; Lamikanra, A. Antibiotic resistance of Helicobacter pylori from patients in Ile-Ife, South-west, Nigeria. Afr. Health Sci. 2007, 7, 143-147. [CrossRef]

51. Shriram, V.; Khare, T.; Bhagwat, R.; Shukla, R.; Kumar, V. Inhibiting Bacterial Drug Efflux Pumps via Phyto-Therapeutics to Combat Threatening Antimicrobial Resistance. Front. Microbiol. 2018, 9, 2990. [CrossRef] [PubMed]

52. Rodrigues, L.; Ainsa, J.A.; Amaral, L.; Viveiros, M. Inhibition of drug efflux in mycobacteria with phenothiazines and other putative efflux inhibitors. Recent Pat. Anti-Infect. Drug Discov. 2011, 6, 118-127. [CrossRef]

53. Pagès, J.-M.; Masi, M.; Barbe, J. Inhibitors of efflux pumps in Gram-negative bacteria. Trends Mol. Med. 2005, 11, 382-389. [CrossRef]

54. Debraekeleer, A.; Remaut, H. Future perspective for potential Helicobacter pylori eradication therapies. Future Microbiol. 2018, 13, 671-687. [CrossRef]

55. Pule, C.M.; Sampson, S.L.; Warren, R.; Black, P.A.; Van Helden, P.D.; Victor, T.C.; Louw, G.E. Efflux pump inhibitors: Targeting mycobacterial efflux systems to enhance TB therapy. J. Antimicrob. Chemother. 2015, 71, 17-26. [CrossRef]

56. Blanco, P.; Hernando-Amado, S.; Reales-Calderon, J.A.; Corona, F.; Lira, F.; Alcalde-Rico, M.; Bernardini, A.; Sanchez, M.B.; Martinez, J.L. Bacterial Multidrug Efflux Pumps: Much More Than Antibiotic Resistance Determinants. Microorganisms 2016, 4, 14. [CrossRef] [PubMed]

57. Opperman, T.J.; Nguyen, S.T. Recent advances toward a molecular mechanism of efflux pump inhibition. Front. Microbiol. 2015, 6, 421. [CrossRef] [PubMed]

58. Zhang, Z.; Liu, Z.-Q.; Zheng, P.-Y.; Tang, F.-A.; Yang, P.-C. Influence of efflux pump inhibitors on the multidrug resistance of Helicobacter pylori. World J. Gastroenterol. 2010, 16, 1279-1284. [CrossRef] [PubMed]

59. Rodrigues, L.; Villellas, C.; Bailo, R.; Viveiros, M.; Aínsa, J.A. Role of the Mmr Efflux Pump in Drug Resistance in Mycobacterium tuberculosis. Antimicrob. Agents Chemother. 2012, 57, 751-757. [CrossRef]

60. Sekyere, J.O.; Amoako, D.G. Carbonyl Cyanide m-Chlorophenylhydrazine (CCCP) Reverses Resistance to Colistin, but Not to Carbapenems and Tigecycline in Multidrug-Resistant Enterobacteriaceae. Front. Microbiol. 2017, 8, 228. [CrossRef]

61. Kumar, S.; Lekshmi, M.; Parvathi, A.; Ojha, M.; Wenzel, N.; Varela, M.F. Functional and Structural Roles of the Major Facilitator Superfamily Bacterial Multidrug Efflux Pumps. Microorganisms 2020, 8, 266. [CrossRef]

62. Garvey, M.I.; Piddock, L.J.V. The Efflux Pump Inhibitor Reserpine Selects Multidrug-Resistant Streptococcus pneumoniae Strains That Overexpress the ABC Transporters PatA and PatB. Antimicrob. Agents Chemother. 2008, 52, 1677-1685. [CrossRef]

63. Shaheen, A.; Afridi, W.A.; Mahboob, S.; Sana, M.; Zeeshan, N.; Ismat, F.; Mirza, O.; Iqbal, M.; Rahman, M. Reserpine Is the New Addition into the Repertoire of AcrB Efflux Pump Inhibitors. Mol. Microbiol. 2019, 53, 596-605. [CrossRef] 
64. Ramón-García, S.; Martin, C.; Thompson, C.J.; Aínsa, J.A. Role of the Mycobacterium tuberculosis P55 Efflux Pump in Intrinsic Drug Resistance, Oxidative Stress Responses, and Growth. Antimicrob. Agents Chemother. 2009, 53, 3675-3682. [CrossRef] [PubMed]

65. Rindi, L. Efflux Pump Inhibitors Against Nontuberculous Mycobacteria. Int. J. Mol. Sci. 2020, 21, 4191. [CrossRef] [PubMed]

66. De Francesco, V.; Zullo, A.; Hassan, C.; Giorgio, F.; Rosania, R.; Ierardi, E. Mechanisms of Helicobacter pylori antibiotic resistance: An updated appraisal. World J. Gastrointest. Pathophysiol. 2011, 2, 35-41. [CrossRef] [PubMed]

67. Pathania, R.; Sharma, A.; Gupta, V.K. Efflux pump inhibitors for bacterial pathogens: From bench to bedside. Indian J. Med. Res. 2019, 149, 129-145. [CrossRef] [PubMed]

68. Tyers, M.; Wright, G.D. Drug combinations: A strategy to extend the life of antibiotics in the 21st century. Nat. Rev. Microbiol. Genet. 2019, 17, 141-155. [CrossRef] [PubMed]

69. Jia, J.; Zhu, F.; Ma, X.; Cao, Z.W.; Li, Y.X.; Chen, Y.Z. Mechanisms of drug combinations: Interaction and network perspectives. Nat. Rev. Drug Discov. 2009, 8, 111-128. [CrossRef]

70. Tsuchiya, M.; Imamura, L.; PARK, J.; Kobashi, K. Helicobacter pylori Urease Inhibition by Rabeprazole, a Proton Pump Inhibitor. Biol. Pharm. Bull. 1995, 18, 1053-1056. [CrossRef] [PubMed]

71. Langtry, H.D.; Markham, A. Rabeprazole: A review of its use in acid-related gastrointestinal disorders. Drugs 1999, 58, 725-742. [CrossRef] 